\begin{tabular}{|c|c|c|c|}
\hline Article Info & RESEARCH ARTICLE & ARAŞTIRMA MAKALESİ & \\
\hline Title of Article & \multicolumn{2}{|c|}{$\begin{array}{c}\text { A Landscape Designment Suggestion for } \\
\text { Trakya University Faculty of Education } \\
\text { Campus }\end{array}$} & \\
\hline $\begin{array}{l}\text { Corresponding } \\
\text { Author }\end{array}$ & \multicolumn{2}{|c|}{$\begin{array}{l}\text { Damla ATiK } \\
\text { Trakya University, Faculty of Architecture, Department of Landscape Architecture } \\
\text { damlazeybekoglu@trakya.edu.tr }\end{array}$} & \\
\hline $\begin{array}{l}\text { Received Date } \\
\text { Accepted Date }\end{array}$ & \multicolumn{2}{|l|}{$\begin{array}{l}08.09 .2020 \\
19.10 .2020\end{array}$} & \\
\hline Author / Authors & $\begin{array}{l}\text { Damla ATIKK } \\
\text { H. Candan ZÜLFIKKAR }\end{array}$ & $\begin{array}{l}\text { ORCID: 0000-0003-3963-3844 } \\
\text { ORCID: 0000-0002-0392-3105 }\end{array}$ & \\
\hline How to Cite & \multicolumn{2}{|c|}{$\begin{array}{l}\text { Atik, D. and Zülfikar, H.,C. (2020). A Landscape Designment Suggestion for Trakya } \\
\text { University Faculty of Education Campus, Kent Akademisi, Volume, } 13 \text { (43), Issue } 4 \\
\text { Pages, 609-627. }\end{array}$} & $\begin{array}{l}\text { Kent Akademisi } \\
\text { Urfban Academy }\end{array}$ \\
\hline
\end{tabular}

\title{
Trakya Üniversitesi Eğitim Fakültesi Kampüsü Çevre Düzenleme Proje Önerisi (TR)
}

\begin{abstract}
:
Universities are scientific and cultural foundations which permit production and sharing of knowledge. They contribute scientific, technologic, cultural, economic and social development of society and countries. University campus are facilities that includes several applications besides education and production of knowledge; permitting socialization, sports and cultural activities with related buildings, having open and green spaces, sheltering and accommodation units within a circulation/transportation network. Campus planning and design processes are one of the indicators of status and identity for a society ant city besides they satisfy the needs of students, academicians and personnel. Existent university buildings and campus areas need revisions in order to catch up the current progresses and innovations, to fulfill the new requirements and to be enabling for better qualified physical and social opportunities. A landscaping project suggestion for Trakya University Faculty of Education (Kosova Settlement) is explained related to the requirement of revision in this study.
\end{abstract}

KEYWORDS: Landscaping, campus arrangement, Trakya University

\section{ÖZ:}

Üniversiteler evrensel bilgi üretimine ve paylaşımına olanak veren bilimsel ve kültürel kuruluşlardır. Toplumun ve ülkenin bilimsel, teknolojik, kültürel, ekonomik ve sosyal gelişimine katkı sağlamaktadırlar. Üniversite kampüsleri ise,

\footnotetext{
${ }^{1}$ Trakya University, Faculty of Architecture, Department of Landscape Architecture, damlazeybekoglu@ $@$ trakya.edu.tr

2 İstanbul University, Faculty of Architecture, Department of City and Regional Planning, candanz@istanbul.edu.tr
} 
eğitim ve bilgi üretim işlevinin yanı sıra, içinde çeşitli uygulamaları barındıran, sosyalleşmeye, sportif ve kültürel aktivitelere imkân veren çeşitli yapılarıyla birlikte açık ve yeşil alanlara sahip olan, barınma ve konaklama birimleri ile birlikte düşünülmüş bir ulaşım ağına sahip tesislerdir. Kampüs planlama ve tasarım çalışmaları, öğrenciler, akademisyenler ve çeşitli görevdeki personelin ihtiyaçlarını karşılamaya yönelik olmalarının yanı sıra, toplum ve kent için statü ve kimlik belirleyen unsurlardan biri olmaktadırlar. Mevcut üniversite yapılarının ve kampüs alanlarının güncel gelişim ve değişimlere adapte olabilmek; yeni gereksinimleri karşılayabilmek ve nitelikli fiziksel-sosyal imkânlar sunabilmek için yenilenmeye ihtiyaçları olmaktadır. Bu ihtiyaçlar kapsamında çalışmada, Trakya Üniversitesi Eğitim Fakültesi Kampüsü (Kosova Yerleşkesi) için hazırlanan çevre düzenleme projesi açıklanmıştır.

ANAHTAR KELIMELER: Çevre düzenleme, kampüs düzenlemesi, Trakya Üniversitesi

\section{“Trakya Üniversitesi Eğitim Fakültesi Kampüsü Çevre Düzenleme Proje Önerisi”}

\section{GÍRIȘ:}

Kampüs, kelime anlamıyla "açık alan" ya da "düzlük" olarak tanımlanmakta; kent içinde veya dışında bir yeşil alanda kurulmuş akademik köy veya akademik ideallerin fiziksel planlamaya yansıması olarak nitelendirilmektedir (Turner, 1995). Kampüsler işlevleri esas olarak eğitim-öğretim, araştırma ve uygulama olan; kullanıcıları için barınma, alışveriş, spor, sağlık ve rekreasyon gibi gerekli yaşam koşullarını sağlayan, kendi kendilerine yeterli üniversite kentleri olarak da tanımlanmaktadır (Türeyen, 2002). Benzer şekilde Erkman (1990), kampüslerin sahip olduğu işlevleri temelde, eğitim, barınma, dinlenme-rekreasyon ve ulaşım olmak üzere dört başlıkta ele almakta; bir kampüsün içerdiği işlevler kadar bu işlevler için tasarlanmış mekânların sirkülasyonla beraber akıcı, bütüncül ve işler olmasına, bir başka deyişle işlevsel organizasyonun doğru kurgulanması gerektiğine dikkat çekmektedir. Kurtoğlu (2010) ise kampüslerin entelektüel bir ortam sağlamak amacıyla farklı insanları ve onlara ait düşünceleri belli sınırlar içinde bir araya getirme ve sosyal alışverişe zemin sağlama amacını vurgulamaktadır. Benzer şekilde kampüslere kullanııı, mimar ve peyzaj mimarı perspektiflerinden bakılabileceğini belirten Yılmaz (2015), özellikle iyi tasarlanmış kampüs düzenlemelerinin, öğrencilerin fiziksel ve zihinsel anlamda yaşam kalitesini iyileştireceğini ifade etmektedir.

Kampüsleri küçük kentlere benzeten Matloob vd. (2014) kampüsleri kent ve yerleşimlerden ayıran özelliklerin kendi fiziksel karakterleri olduğunu ifade etmektedirler. Özellikle peyzaj özellikleri ile karşılama mekânları olduklarını, ilgi çekici manzara sunduklarını, kullanıcıların daha güvenli ve konforlu hissettiklerini ve yollarını rahatıkla bulabildiklerini de eklemektedirler (Matloob, Sulaiman, Ali, Shamsuddin, \& Mardyya, 2014). Öztürk (2009) kampüs yapılarını kent bağlamında ele aldığı çalışmasında kampüs planlama politikalarını üç başlık altında incelemektedir:

- Organizasyonel yaklaşım

- Reorganizasyonel yaklaşım

- Dönüşümsel yaklaşım

Yazar, organizasyonel planlama yaklaşımında ülke ve bölge koşullarının göz önünde bulundurulduğunu; mevcut eğitim koşulları ve kullanıcı sayısının değerlendirildiğini ve ardından planlamaya gidildiğini ifade etmektedir. Bu planlama yaklaşımına Ege Üniversitesi Kampüsü (1958), Orta Doğu Teknik Üniversitesi Kampüsü (1961), ve İstanbul Teknik Üniversitesi Ayazağa Kampüsü (1971) örnek gösterilmektedir. Reorganizasyonel planlama yaklaşımında, meydana gelen yeni gereksinimleri karşılamak için, var olan master plan üzerinden ek planlamalar yapıldığını veya yeni bir master plan üretildiğini belirtmektedir. Buna göre binalar, yollar ve yeşil alan düzenlemesi gibi fiziksel özellikler yeniden programlanmaktadır. Dönüşümsel planlama yaklaşımında ise mevcut bir bina veya binalar grubunun ve bunların bulunduğu alanın, üniversite gereksinimleri doğrultusunda dönüştürülmesine yönelik bir planlama yapılmaktadır. Bir binanın kampüse dönüştüğü (İTÜ Taşkışla, TÜ Makedonya) ve sadece restorasyon sürecine tabi olan uygulamaların yanı sıra, mevcut binaların restorasyon ve iç düzenlemesine ek olarak yeni yapılanmaların ve çevre düzenlenmelerinin yapılması da dönüşümsel planlama kapsamında ele alınmaktadır.

Kampüs planlama yaklaşımlarında bahsedilen yeni gereksinimler; bir başka deyişle kampüslerin değiş̧imi ve buna bağlı büyüme nedenleri Erkman (1990) tarafından şu şekilde sıralanmıştır:

- Eğitim amaç ve yöntemlerinde değişme,

- Araştırma amaç ve yöntemlerinde değişme, 
- Mevcut dallara yapılan ilaveler; öğretim alanlarının gelişmesi ve/veya yeni öğretim alanlarının açılması,

- Yeni fakülte, enstitü ve yüksekokulların kurulması,

- Öğrenci sayısının artması

Karakaş (1999), üniversitelerdeki gelişmeyi fiziksel büyüme ölçeklerine göre altıya ayırmıştır:

- Yeniden düzenlemek

- Eklentiler yapmak

- Yeni yapilar yapmak

- Yeni kullanım alanları sağlamak

- Uydu kampüsler kurmak

- Yeni kampüsler kurmak

Dolayısıyla mevcut kampüs yapılarının gelişim ve değişime adapte olabilmek; yeni gereksinimleri karşılayabilmek; nitelikli fiziksel ve sosyal çevreye sahip olabilmek; peyzaj ve kimlik öğeleriyle birlikte tercih edilebilmek ve imaj değerini arttırabilmek için düzenlemelere ihtiyaçları olmaktadır. Kampüs planlama, tasarım ve düzenlemeleri mimar, peyzaj mimarı ve kent plancılarının ortak kararları üzerinden ele alınmalı; üniversitenin sahip olduğu ekonomik koşullar da göz ardı edilmemelidir. Tüm bu bilgiler doğrultusunda çalışmaya konu olan Trakya Üniversitesi Eğitim Fakültesi Kampüsü (Kosova Yerleşkesi) çevre düzenleme proje önerisi, dönüşümsel yaklaşımla ele alınmış olup; kampüsteki mevcut birimlere yapılan ilaveler; öğretim alanlarının gelişmesi ve/veya yeni öğretim alanlarının açılması, yeni fakülte kurulması ve öğrenci sayısının artması ile yeniden düzenleme kapsamında değerlendirilmiştir.

\section{MATERYAL ve METOT:}

Çalışmanın materyali Trakya Üniversitesine ait Edirne merkez ilçe Şükrüpaşa Mahallesi'nde bulunan Eğitim Fakültesi Kampüsü'dür (Kosova Yerleşkesi) (Şekil 1). Eğitim Fakültesi, 1969-1970 eğitim-öğretim yılında eğitim süresi 3 yıl olarak "Edirne Eğitim Enstitüsü” adı altında öğretime başlamış olup, Matematik ile Fen ve Tabiat Bilgileri branşlarının eğitimini içermektedir. Daha sonra bu iki branşta gece öğretimine geçilmiş 1978-1979 eğitim-öğretim yılında eğitim süresi 4 yıla çıkarılarak "Edirne Yüksek Öğretmen Okulu " adını almıştır. 1981-1982 eğitim-öğretim yılında eğitim süresi 2 yıla indirilmiş; 41 sayılı kanun hükmünde kararname ile Trakya Üniversitesi'ne bağlanarak "Edirne Eğitim Yüksekokulu" adını almıştır. 1989-1990 eğitim-öğretim yılından itibaren eğitim süresi 4 yıla çıkarılan yüksekokulun adı, 11 Temmuz 1992 tarih ve 12281 sayılı Resmi Gazete'de yayınlanan 3.7.1992 tarih ve 3837 sayılı kanun ile "Eğitim Fakültesi” olarak değiştirilmiştir (URL 1). Fakültede bulunan anabilim dalları 13 adettir. Bunlar, Sınıf Öğretmenliği, Okul Öncesi Öğretmenliği, Fen Bilgisi Öğretmenliği, Rehberlik ve Psikolojik Danışmanlık, Matematik Öğretmenliği, Müzik Öğretmenliği, Türkçe Öğretmenliği, Bilgisayar Öğretmenliğgi, Resim Öğretmenliği, Sosyal Bilgiler Öğretmenliği, Zihinsel Engelliler Öğretmenliğii, Almanca Öğretmenliği ve İngilizce Öğretmenliğidir.

Kampüs toplamda yaklaşık $23.000 \mathrm{~m}^{2}$ alana sahip olup, bunun yaklaşık $7000 \mathrm{~m}^{2}$ 'si bina oturum alanıdır. Yine yaklaşık $6000 \mathrm{~m}^{2}$ kadar yeşil ve yapılaşmamış alan bulunmaktadır. Geri kalan alanın büyük bir kısmı otopark ve yollardan oluşmaktadır (Şekil 2).

Trakya Üniversitesi Eğitim Fakültesi Kampüsü (Kosova Yerleşkesi) Çevre Düzenleme Projesi talebi Mimarlık Fakültesi Dekanlı'ğı aracıllığıla Haziran 2016 tarihinde tarafımıza bildirilmiştir. Projede, mevcut yapıların dış mekânlarını daha kullanışlı hale getirmek, iletilen talepler ve tespit edilen ihtiyaçlar doğrultusunda dış mekân kullanım alanını arttırarak yeni düzenlemeler yapmak amacıyla bir takım önerilerde bulunulmuştur.

Çalışma yöntemi literatür araştırması, örnek proje incelemesi, Kosova Yerleşkesi'nde analizlerin yapılması (mevcut durum tespiti-ölçme-fotoğraflama), analizlerin Autocad ortamına aktarılması, tasarım çalışmalarının SketchUp programında modellenmesi ve kampüsün uygulama aşamasından sonra ziyaret edilerek ilk durumu ile karşılaştırılması olarak gerçekleştirilmiştir. Bu karşılaştırma bulgular bölümünde aşağıdaki gibi ifade edilmiştir:

- Öncesi 2016: Sorunlar / Tespitler

- Tasarım 2016: Öneriler 
- Sonras1 2018: Uygulama

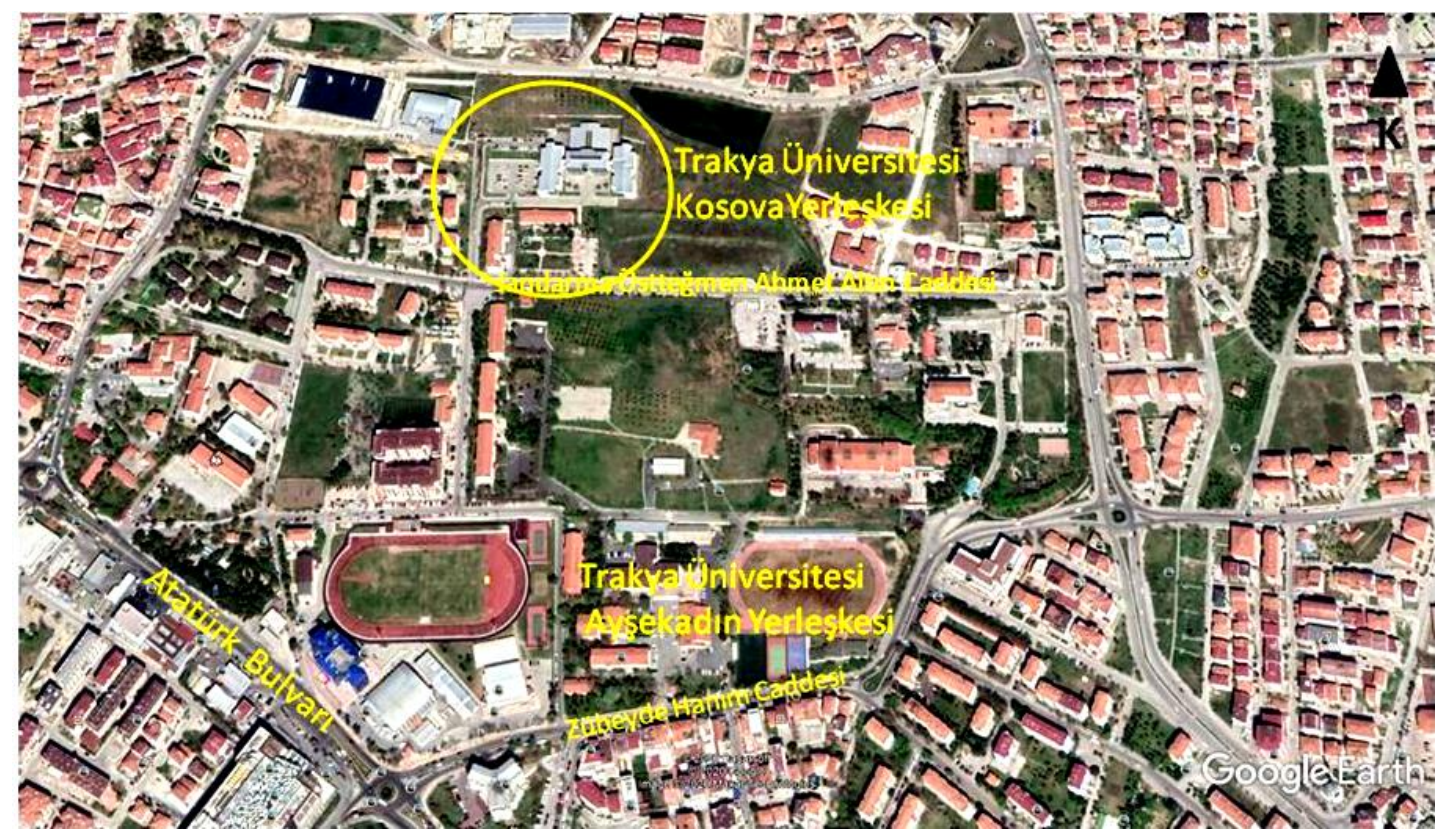

Şekil 1. Trakya Üniversitesi Kosova Yerleşkesi uydu görüntüsü (URL 2)

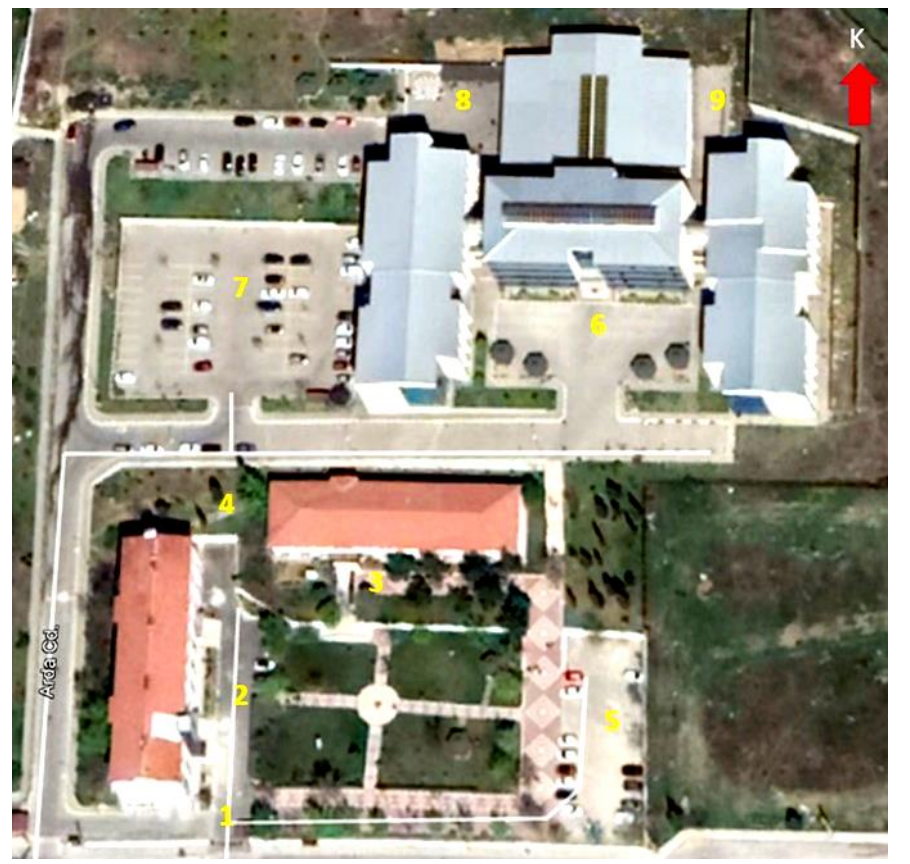

1. Yerleşke Giriși

2. Güzel Sanatlar Bölümleri Binası önü

3. Dekanlık Binası önü

4. Dekanlık Binası yanı,

5. Dekanlık otopark1

6. Eğitim Fakültesi Binaları önü

7. Eğitim Fakültesi otoparkı

8. Kantin önü ve çevresi

9. Konferans Salonu çevresi

Şekil 2. Kosova Yerleşkesi çalışma alanları. Uydu görüntüsü: (URL 3) 2.1. Örnek Projelerin İncelenmesi

Yılmaz (2015) Süleyman Demirel Üniversitesi Doğu Kampüsü içinde bulunan ve 30.103 m²'lik bir alanı kapsayan Orman Fakültesi Kampüs düzenleme önerisinde, tekil bina dışında kalan açık alanı, karşılama mekânı, etkinlik alanı ve bitki tanıma derslerine yönelik uygulama alanı olacak şekilde yumuşak zemin ile yeşil alan ağırlıklı olarak tasarlamıştır.

A Landscape Designment Suggestion for Trakya University Faculty of Education Campus

Journal of Urban Academy | Volume: 13 Issue: 4 | ISSN: 2146-9229

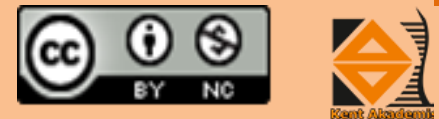


Yapılan düzenleme önerisinde kampüs kullanıcılarının fiziki mekânları bitkisel doku ile bütünleştirmeleri; mekân kullanımı ve etkileşimi ön planda tutulmuştur. Kosova Yerleşkesi'nde uygulama alanına ihtiyaç duyulmamış olup, mevcut bina ve sert zemin yoğunluğu yumuşak zemin ve yeşil alan kullanımlarıyla dengelenmiştir.

Ertekin ve Çorbacı (2010), 1006.8 da'lık bir alanda yer alan Karabük Üniversitesi Balıklar Kayası Kampüsü Yerleşim Planını giriş, sirkülasyon, park alanları, tören alanı, amfitiyatro, sosyal tesis, satış birimleri, kır kahvesi ve spor tesisleri işlevleriyle projelendirmişlerdir. Oldukça geniş bir alana yayılan bu kampüs büyüklüğü bakımından çalışma alanıyla karşılaştırılamasa da, yazarların düzenli yerleşimin görülmediği kampüs sorunlarından akademik ve sosyal birimler arasındaki bağlantı noksanlığına çektikleri dikkat açısından örnek alınarak değerlendirilmiştir. Alanları kimliksiz ve kullanışsız hale getiren bu sorun, Kosova Yerleşkesi'nde yaya odaklı ve kullanıcı ihtiyaçlarına yönelik çözümler sunularak ele alınmıştır.

Doğal ortam içinde yaya odaklı kampüs yaşamı hedefleyen bir diğer çalışma Çanakkale Onsekiz Mart Üniversitesi Terzioğlu Yerleşkesinde yapılmıştır. Çanakkale kentinin en güzel noktasında bulunan ve 3 hektarlık bir alanı kapsayan yerleşke zorlu bir topoğrafyaya sahiptir. Sağlık vd (2020), kampüsü yürüyerek deneyimlemek ve keşfetmek hedefi ile bir kurgusal konsept oluşturmuş; doğal yeşil dokuda yürüyüş yollarının tasarlanması ile kampüse karşı aidiyet hissinin geliştirilmesine katkı sağlamışlardır. Buna istinaden, Kosova Yerleşkesi’nde öğrencilerle birlikte tüm diğer kullanıcıların aidiyet hissini pekiştirmek ve doğa ile temaslarını arttırmak amaçlanmıştır.

Öğrencilere çok amaçlı ve zengin bir mekânsal deneyim sunmayı amaçlayan Birinci vd. (2020), 383,884 m²’lik bir alanda bulunan İzmir Demokrasi Üniversitesi Uzundere Kampüsü için hazırladıkları genel yaklaşım planı önerisinde akademik ve sosyal hayatı birleştirme gerekliliğini vurgulamışladır. Kosova Yerleşkesi'ni kullanan öğrenci, akademik ve idari personelin mesai ve ders saatleri aralarında/dışında ortak kullanacakları mekânları düzenleyerek sosyal hayatlarına katkı sağlamak, çalışmamızın öncelikleri arasındadır.

Genel yaklaşım ve planlama kararlarına ilişkin olarak incelenen, ölçek olarak nispeten Kosova Yerleşkesi’nden büyük alanlara sahip örneklerle birlikte, Kosova Yerleşkesi'ne yakın ölçekte olan ve öneriler açısından benzerlik bulunan bir başka çalışma ise Diyarbakır'da yapılmıştır. 27000 Dönüm arazi üzerinde yer alan Dicle Üniversitesi Kampüsünde, erişilebilirlik standartlarını değerlendirdikleri çalışmalarında Çorbacı vd. (2020) yaya yolları, girişler, merdivenler, rampalar, kaldırımlar, donatı elemanları, otopark ve kaplamalar üzerinden önerilerde bulunmuşlardır. Son olarak bitkisel tasarım özelinde incelenen çalışmalardan bir tanesi Yeşil (2017) tarafından Ordu Üniversitesi Cumhuriyet Yerleşkesinde yapılmıştır. Bina oturum alanları çıkarıldığında hâlihazırda kullanılan yaklaşık 115.400 m2 'lik bölümde bitkisel tasarım ve uygulama çalışması gerçekleştirilmiştir. Bir diğer çalışma ise 802.630 m² $^{2}$ lik açık alan ve 18.996 $\mathrm{m}^{2}$ 'lik kapalı alana sahip Zonguldak Bülent Ecevit Üniversitesi Çaycuma Kampüsünde Akça ve Gülgün Aslan tarafından yapılmıştır (Akça \& Gülgün Aslan, 2019). Yazarlar, tasarım kriterlerine göre dikilmeyen bitkilerin kullanım alanlarının kısıtlandığını ifade ederek, olumsuz görüntüler ve işlevsiz yaya yolları tespit etmişlerdir. Doğru ve yanlış kullanımları değerlendirerek belirledikleri etkinlik alanlarına göre bitkisel tasarım önermişlerdir. Bu çalışmalara istinaden Kosova Yerleşkesi'nde bina ve otopark izlerinin kapladığı geniş alanlar dışındaki mekânlara bitkisel öneriler getirilmiş ve yaya yolları, girişler, merdivenler, rampalar, donatı elemanları, otopark ve malzeme iyileştirilmeleri üzerinden önerilerde bulunulmuştur.

Literatür araştırması ve örnek çalışmaların incelenmesinden sonra Kosova Yerleşkesi’ne ait 1/1000 ölçekli hâlihazır paftalar ve alan sınırı verisi temin edilmiştir. Topografik yapıya ilişkin kot bilgileri girildikten sonra, yerinde gözlem ve fotoğraf tespiti yapılarak mevcut bitkilerin türleri ve konumları saptanmıştır. Alan çalışması sırasında hâlihazır harita ile çakışmayan veriler için, yeniden ölçüm yapılarak rölöveleri çıkarılmıştır. Yaya ve araç sirkülasyonu gözlemlenerek ulaşım izleri belirlenmiş; ulaşılabilirlik ve erişilebilir kampüs kapsamında aksayan yönler ve yoğunluklar tespit edilmiştir. Sonrasında, kampüsteki çalışma alanları proje önerisi geliştirmek üzere 9 kısma ayrılmıştır (Şekil 2). Söz konusu bu alanlarda mevcut imkânlar değerlendirilmiş; "kullanılan", "kullanılmayan" ve "kullanılamayan" alanlar ile ihtiyaçlar tespit edilmiştir. Talep edilen ve ihtiyaç duyulan fonksiyonlar üzerine öğrenciler, görevli akademik ve idari personelin aktif olarak ve doğrudan değerlendirecekleri donatılar, mekânlar ile beraberinde yapısal ve bitkisel düzenleme önerileri getirilmiştir. Kullanıcıların yanı sıra ziyaretçilerin ve servis elemanlarının da göz önünde bulundurulduğu tasarımda dikkat edilen hususlar Tablo 1'de gösterilmiştir.

Tablo 1. Kosova Yerleşkesi Planlama ve Tasarım Stratejisi 


\begin{tabular}{l|l} 
Planlama Politikası & Dönüşümsel \\
\hline Yaklaşım & Yaya Odaklı / Erişilebilir \\
\hline Yapısal Tasarım & Donatı tasarımı, iyileştirmeler \\
\hline Bitkisel Tasarım & Estetik ve Fonksiyonel düzenlemeler \\
\hline
\end{tabular}

Yerli ve Özdede (2017) de kampüs tasarımının yaya odaklı olduğuna işaret ederek; tüm işlev alanlarını birleştirici özelliğinden dolayı önceliğin yaya ulaşımına verilmesi gerektiğini ifade etmişlerdir. Buna göre, Tablo 1.'de gösterilen tasarım stratejisine uygulanan kararlar aşağıdaki gibidir:

- Yayaların kampüs içindeki bütün binalara ve diğer kullanım alanlarına ulaşımının sağlanması gerekmektedir.

- Yaya yolları fakülte birimleri, idari birimler ve sosyal birimler arası yoğunluğu taşımak için geniş, kesintisiz ve erişilebilir olmalıdır.

- Yaya dolaşımı ve ulaşımı sırasında çevrenin fiziksel, görsel ve psikolojik algısını geliştirecek düzenlemeler yapılmalıdır.

- Yaya ulaşımında zorlayıcı eğim kullanımları giderilmeli; özel gereksinimli bireylerin erişimi de düşünülmelidir.

- Yaya ulaşımındaki malzeme kullanımında güvenlik, çevreye ve iklim şartlarına uygunluk, dayanıklılık ve kolay bakım kriterleri dikkate alınmalıdır.

- Yaya-taşıt trafiğindeki çakışmalar (mümkünse ayrılmalı) en aza indirgenmeli; kesişim ve kavşaklar dikkate alınmalıdır. Otopark düzenlemesi standartlara uygun yapılmalı, özel gereksinimli birey otopark alanı bulunmalı ve zemin kaplamasında su geçirimliliğini sağlayan malzeme kullanılmalıdır. Otopark alanında uygun bitkilendirme tasarımı ile yansıma ve ısınma azaltılmalı, gölge sağlanmalıdır.

- Yapısal olarak, öğrencilerin, akademik ve idari personelin dış mekânlarda vakit geçirmelerine imkân tanıyacak üst örtülü ve açık alan oturma birimleri tasarlanmalıdır.

- Otopark ve rampalar düzenlenmeli; döşemeler iyileştirilmelidir.

- Sağlıksız durumda olmadıkları veya tasarım açısından ciddi riskler barındırmadıkları sürece mevcut bitkiler korunmalıdır.

- Bunlara ilave olarak yeni ağaç, ağaççı, çalı, yer örtücü ve sarılıcı bitki kullanılmalıdır.

- Yeni kullanılacak bitkiler sınırlayıcı, gölge amaçlı, soliter kullanım, serbest kullanım, aks belirleyici olmak üzere estetik ve fonksiyonel ihtiyaçları karşılamalıdır.

- Alanın çeşitli yerlerinde istenmeyen görüntüler sergileyen istinat duvarları bitkilendirilerek tasarıma görsel katkı sağlanmalıdır.

\section{BULGULAR:}

Belirlenen çalışma alanlarından ilki yerleşke girişidir. Yerleşke sınırında duvarlarda yeterli yeşil doku bulunmadığ tespit edilmiştir. Bu sınırın daha net algılanması için duvarların herdem yeşil sarılıcı bitkilerle desteklenmesi önerilmiş; ancak uygulama safhasında müdahale yapılmadığı görülmüştür. Diğer çalışma alanlarının uygulama öncesi durumları, modellemeleri ve uygulama sonrası görselleri Tablo 2-9 arasında gösterilmiştir.

Tablo 2. Güzel Sanatlar Bölümleri Binası önüne ait tespit ve öneriler ile alanın uygulama sonrası durumları

\section{GÜZEL SANATLAR BÖLÜMLERİ BİNASI ÖNÜ}




\section{Öncesi 2016: Sorunlar / Tespitler}

Girişte bulunan Eğitim Binası önündeki asfalt zemin görsel olarak olumsuz etki yaratmaktadır.

$\mathrm{Bu}$ alanda bulunan üst örtü elemanı niteliksizdir.
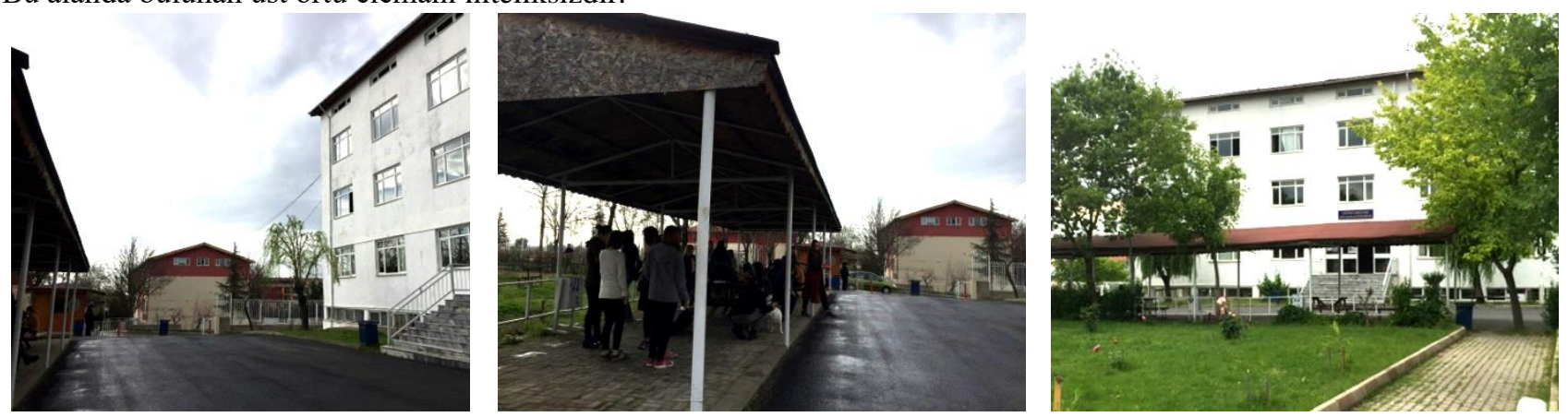

\section{Tasarım 2016: Öneriler}

Asfalt zeminin değiştirilmesi talep edilmediği için, aks boyunca araç geçişini önlemeyecek şekilde bitkisel düzenleme yapılmıştır.

$\mathrm{Bu}$ alanda bulunan üst örtü elemanı yerine yeşil alan üzerinde üst örtü elemanları yeniden konumlandırılmıştır.

Kısa teneffüs aralarında kullanılmak üzere alanda uygun yerlere oturma birimleri yerleştirilmiştir.
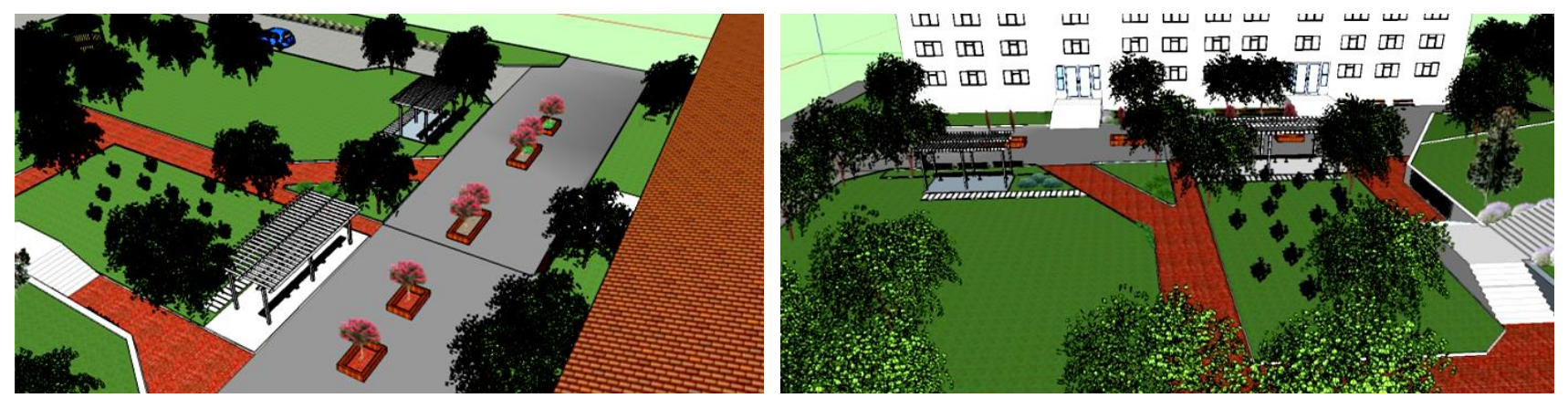

\section{Sonrası 2018: Uygulama}

Önerilen bitkisel düzenlemeler gerçekleştirilmemiştir. Üst örtü elemanının öneriye uygun değiştirilmediği; malzeme olarak iyileştirildiği görülmektedir. Oturma birimlerinin Bina cephesindeki yenilik göze çarpmaktadır.
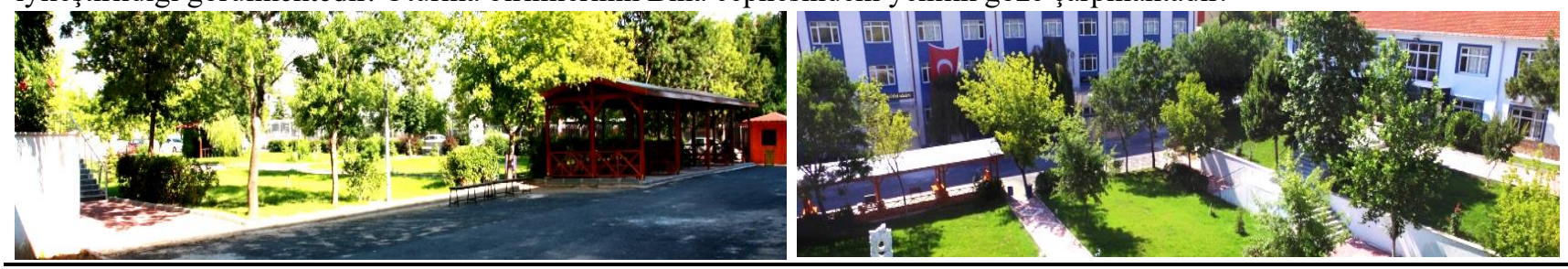

Tablo 3. Dekanlık binası önüne ait tespit ve öneriler ile alanın uygulama sonrası durumları

\section{DEKANLIK BINASI ÖNÜ}

A Landscape Designment Suggestion for Trakya University Faculty of Education Campus

Journal of Urban Academy | Volume: 13 Issue: 4 | ISSN: 2146-9229

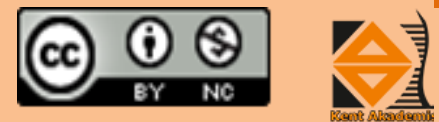




\section{Öncesi 2016: Sorunlar / Tespitler}

Özel gereksinimli bireylerin Dekanlık girişine ulaşımı mümkün değildir.

Döşeme malzemesinde ve yolun tesviyesinde bozulmalar mevcuttur.

Yaya yolu genişliği yetersizdir.

Yeşil alan içinde, toprak doldurulmuş eski havuz kötü görüntü oluşturmaktadır.
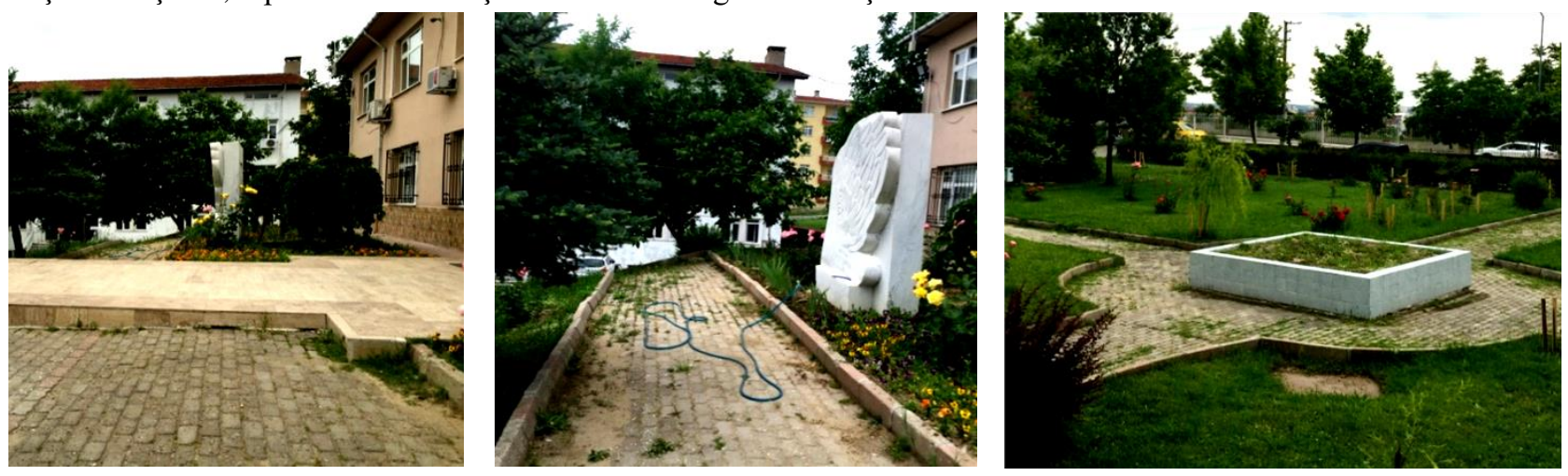

\section{Tasarım 2016: Öneriler}

Dekanlık binası girişi rampa çözümleri ile ulaşılabilir hale getirilmiştir.

Yaya yolunun rampaya bağlantısı yeşil alan içinden sağlanmıştır. Bu amaçla mevcut yol güzergâhı yeniden düzenlenerek genişletilmiştir. Bu geçişte mevcut ağaçların korunmasına dikkat edilmiştir.

Tesviyenin düzeltilmesi ile kırmızı taban tuğlası önerilmiştir.

Toprak doldurulmuş eski havuz yeni yol bağlantı düzeni dikkate alınarak kaldırılmıştır.
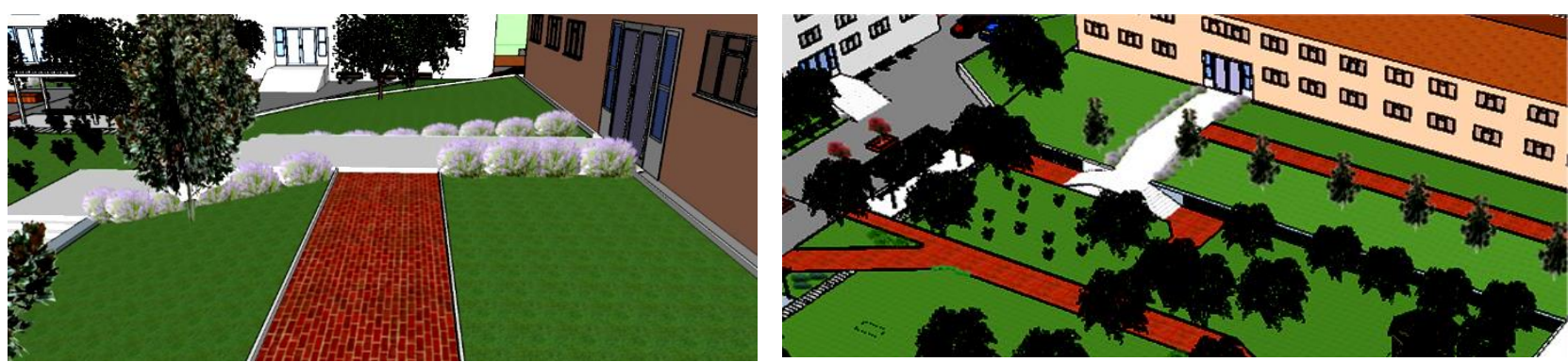

\section{Sonrası 2018: Uygulama}

Döşemede, öneriye benzer şekilde renkli malzeme kullanıldığı, havuzun kaldırıldığı ve Dekanlık binasının önündeki yol ile birlikte yenilendiği görülmektedir.
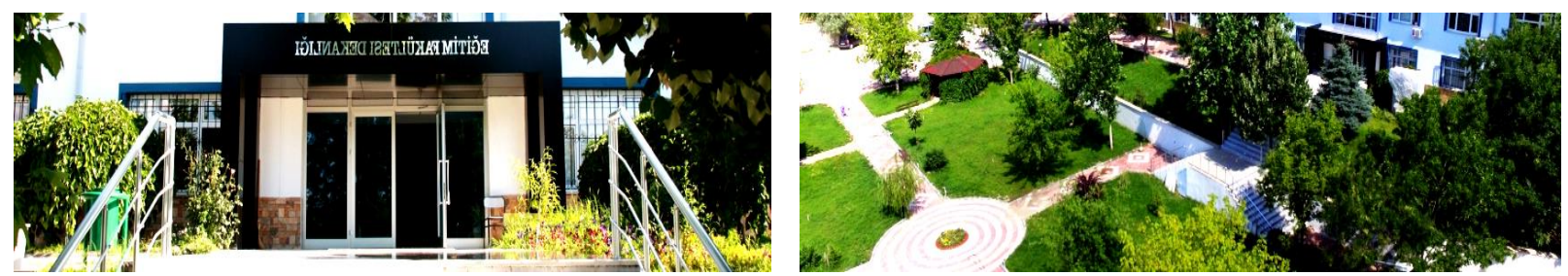

Tablo 4. Dekanlık binası yanına ait tespit ve öneriler ile alanın uygulama sonrası durumları

\section{DEKANLIK BİNASI YANI}

A Landscape Designment Suggestion for Trakya University Faculty of Education Campus Journal of Urban Academy | Volume: 13 Issue: 4 | ISSN: 2146-9229

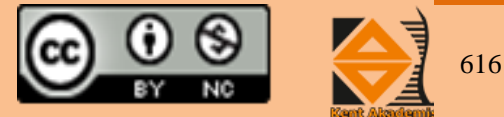




\section{Öncesi 2016: Sorunlar / Tespitler}

Dekanlık binası kuzey cephesi istinat duvarına bakmaktadır.

Dekanlık binası çalışanları için kısa süreli dinlenme aralarında kullanacakları alan bulunmamaktadır

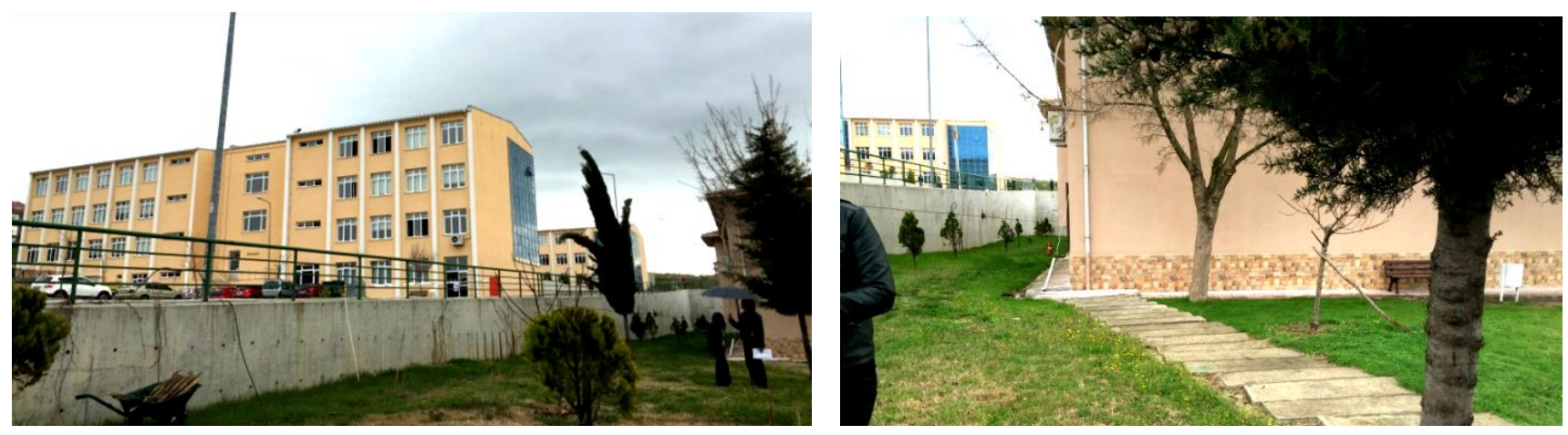

\section{Tasarım 2016: Öneriler}

Dekanlık binasının kuzey yönündeki istinat duvarı herdem yeşil sarılıcı bitkilerle yeşil duvar haline getirilerek görüntüsü estetik açıdan iyileştirilmiştir.

Dekanlık binası batı cephesi yönünde, çalışanlar tarafından kullanılmak üzere üst örtülü oturma birimi önerilerek, gölgeli bir dinlenme alanı oluşturulmuştur.
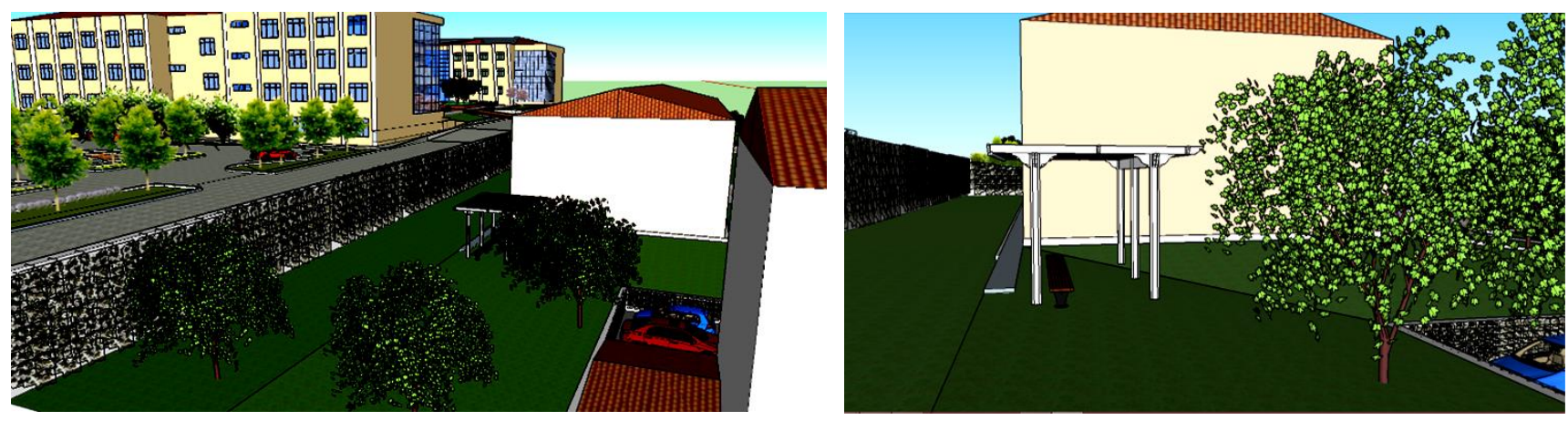

\section{Sonrası 2018: Uygulama}

Müdahalede bulunulmamıştır.

Tablo 5. Dekanlık otoparkına ait tespit ve öneriler ile alanın uygulama sonrası durumları

\section{DEKANLIK OTOPARKI}

A Landscape Designment Suggestion for Trakya University Faculty of Education Campus

Journal of Urban Academy | Volume: 13 Issue: 4 | ISSN: 2146-9229 


\section{Öncesi 2016: Sorunlar / Tespitler}

Otopark yolunda ulaşımı engelleyen ağaç ve çalılar bulunmaktadır.

Mevcut istinat duvarlarının görüntüsü alanı olumsuz etkilemektedir.

Otopark düzenlemesi nitelikli değildir; yaya ve araç trafiği kesişmekte olup, yayalar otopark içinden geçmektedirler.

Mevcut bitkilerin gelişimi için yeterli yeşil alan bulunmamaktadır.

Otoparkta gölge sağlayacak bitkisel düzenleme yetersizdir.

Otopark ile yeşil alanı ayıran duvarın fonksiyonu bulunmaktadır.

Otoparktan Dekanlık Binası kotuna bağlantı sağlayan rampa dik olup, homojen düzenleme yapılmamıştır. Rampa bitiminde bağlantıyı devam ettiren merdivenin kaplama malzemesi yağışıı havalarda kaygan olabileceği için uygun değildir.
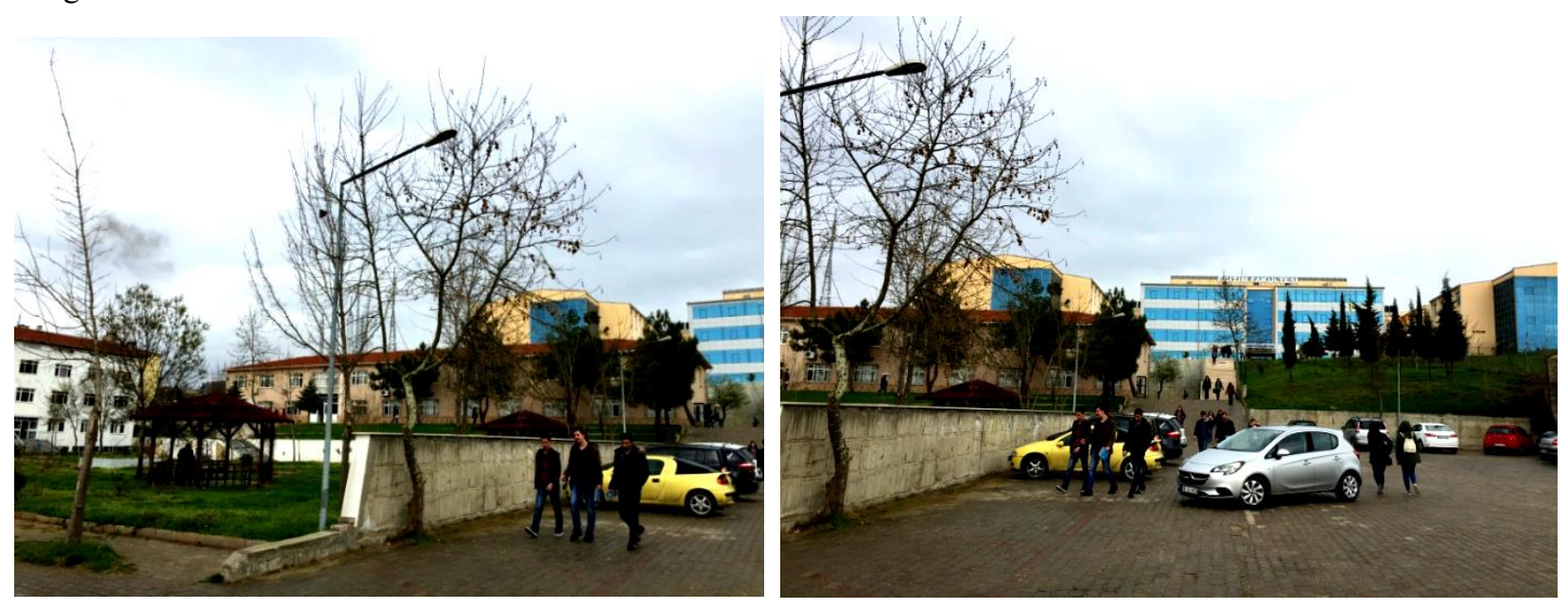

\section{Tasarım 2016: Öneriler}

Otopark yolunda ulaşımı engelleyen ağaçlar yeşil alan düzenlemesine dâhil edilmiştir.

İki aracın yan yana geçebileceği durumlar için yanaşma-bekleme cebi oluşturulmuştur.

Mevcut otopark ile yeşil alanı ayıran duvarın rampanın bitiminden sonraki kısmı kaldırılmıştır. Böylece yeni yaya yolu güzergâhı ile rampa bağlantısı sağlanmış; yayaların otopark içinden geçişi kısıtlanmıştır.

Otoparkta araçların park düzeni çizilmiş ve düzenlenmiştir.
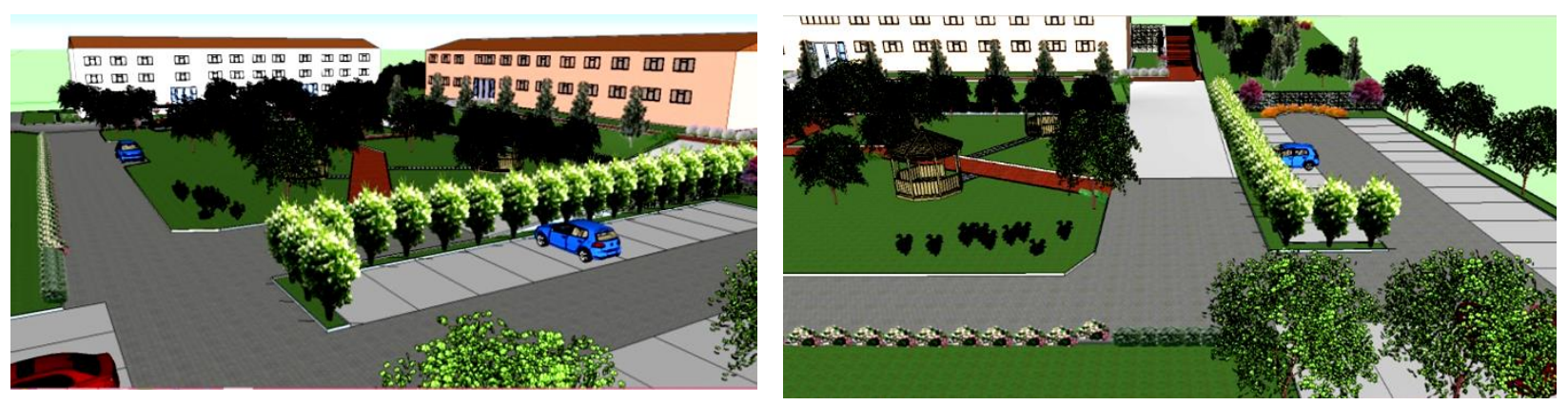

Mevcut bitkilerin gelişimi için yeterli yeşil alan önerilmiştir.

Otopark alanı gölge sağlamak ve alan sınırını belirlemek amacıyla bitkilerle yoldan ayrılmıştır.

Sınır duvarı herdem yeşil sarıcı bitkiler kullanılarak yeşil duvar haline getirilerek otoparkın sert görüntüsü giderilmiştir.

Mevcut rampa yeniden düzenlenerek eğimi uygun hale getirilmiştir. Rampa bitiminde bağlantıyı devam ettiren merdivenin kaplama malzemesi için kaymayı önleyecek ve bütünlüğü sağlayacak kırmızı taban tuğla önerilmiştir. 


\section{Sonrası 2018: Uygulama}

İstinat duvarının kaldırıldığı, rampa eğiminin düzenlendiği, döşemelerin iyileştirildiği ve merdiven kaplama malzemesinin değiştirildiği görülmektedir. Yaya ve araç trafiğinin, farklı döşeme kaplamasıyla ayrımlandığı tespit edilmiştir. Otopark sınırını vurgulamak ve gölge sağlamak için önerilen bitkilendirmenin yapılmadığı görülmektedir.
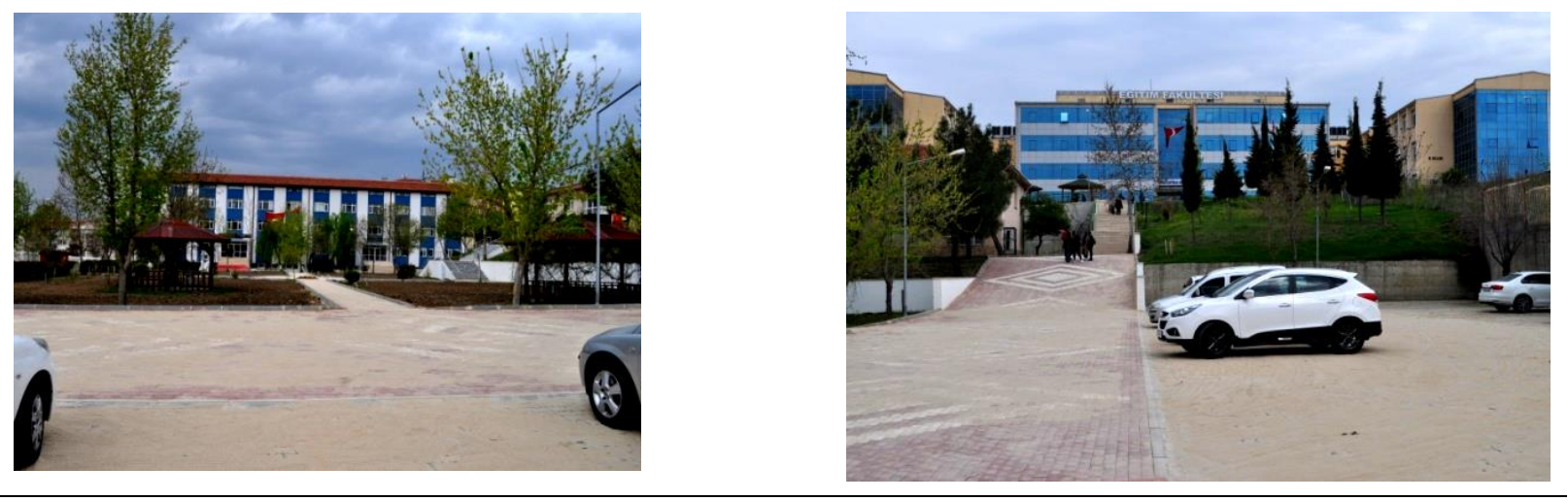

Tablo 6. Eğitim Fakültesi Binaları önüne ait tespit ve öneriler ile alanın uygulama sonrası durumları

\section{EĞITIM FAKÜLTESİ BINALARI ÖNÜ}

\section{Öncesi 2016: Sorunlar / Tespitler}

Bina önündeki alan kilit parke taşıyla kaplıdır. Yeşil alan yetersizdir.

Bina girişlerinde özel gereksinimli bireyler için düzenlenmiş ulaşım çözümleri yeterli değildir.

Kısa süreli dinlenme alanları ile oturma birimleri ihtiyacı karşılamamaktadır.
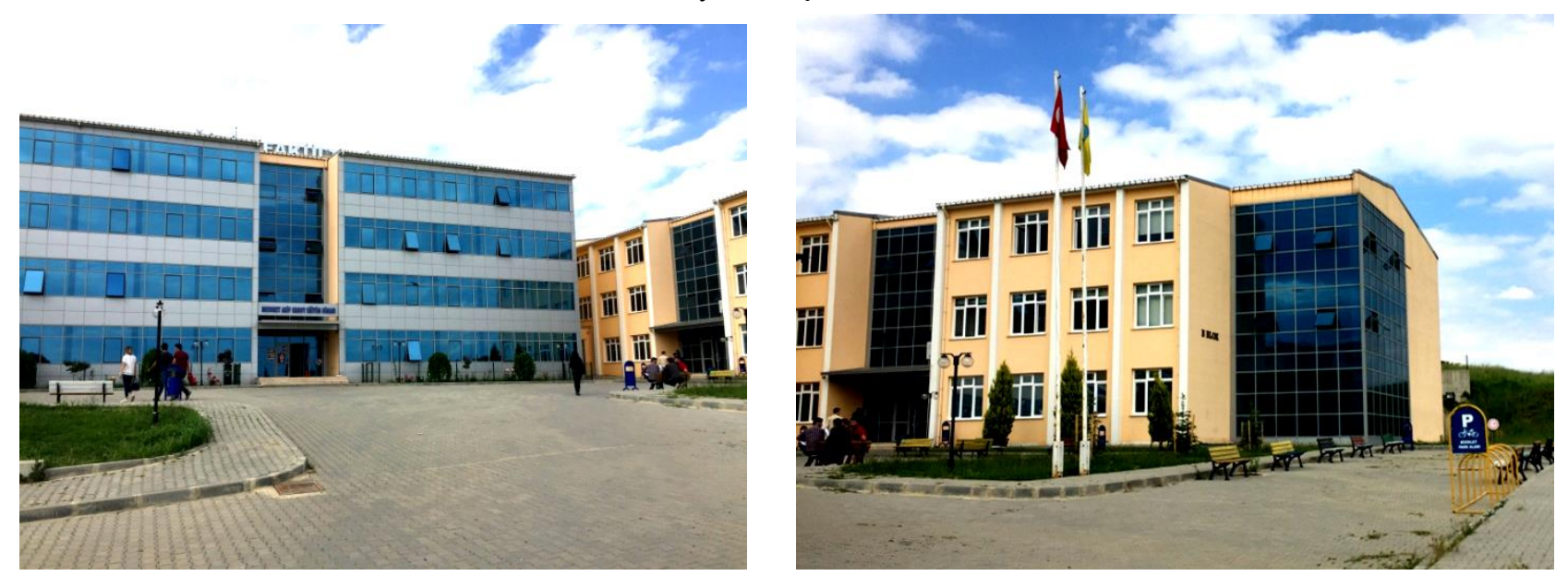


\section{Tasarım 2016: Öneriler}

Bina önünde yeşil ve gölgeli alanlar önerilmiştir.

Alana değer katacağı düşünülen ağaçlar ile gölge sağlanmış; oturma birimleri bir düzen dâhilinde yerleştirilmiştir.

Bina giriş akslarını vurgulamak ve alana renk katarak monotonluğu gidermek için kırmızı taban tuğla ile yol aksının vurgulanması tavsiye edilmiştir.

Bina girişlerinde uygun eğimde rampa çözümleri uygulanmıştır.
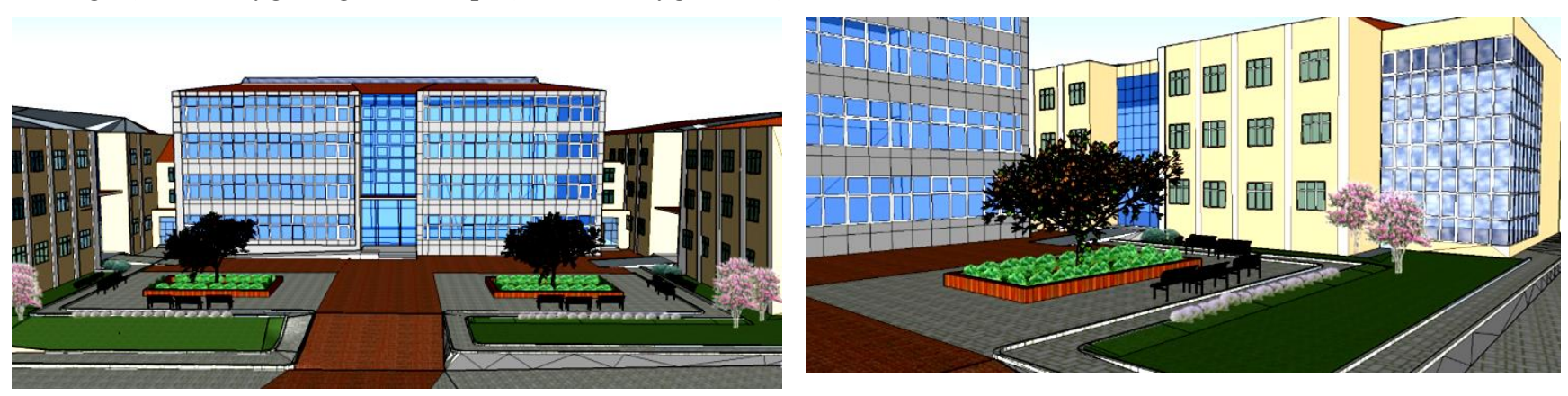

\section{Sonrası 2018: Uygulama}

Bu alanda önerilen ağaçlar ve düzenlemeler yerine üst örtülü oturma birimleri yerleştirildiği görülmektedir. Döşemelerin henüz iyileştirilmemesinin ekonomik sebeplerden kaynaklandığı düşünülmektedir.

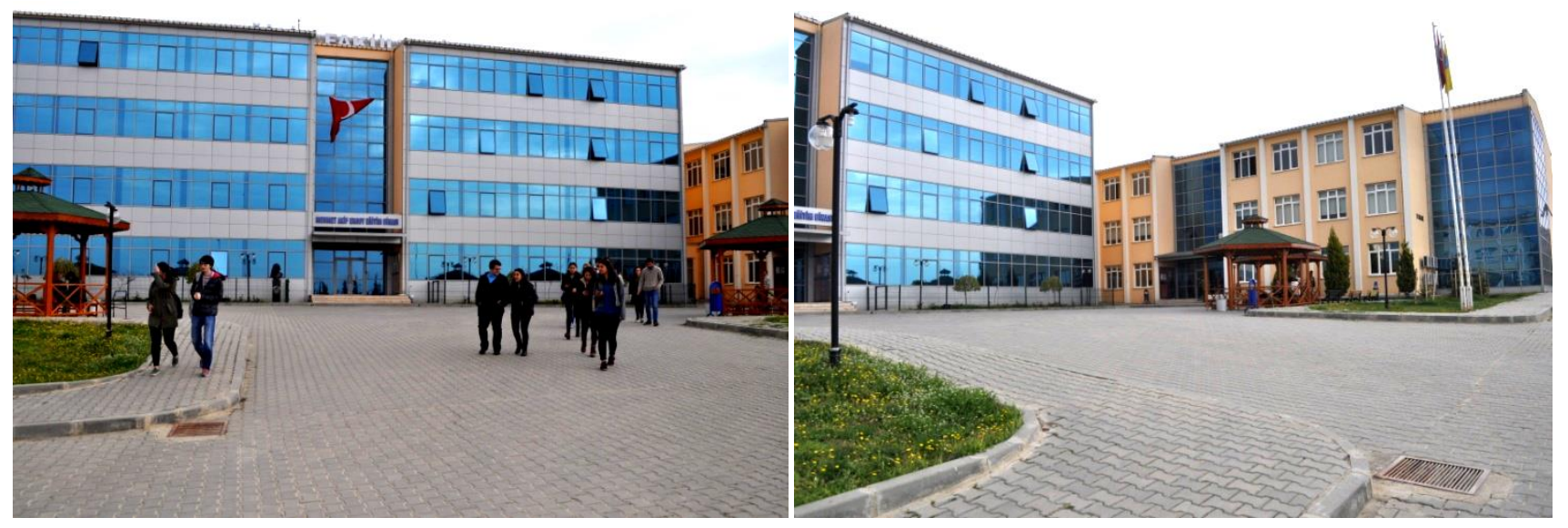


Tablo 7. Eğitim Fakültesi otoparkına ait tespit ve öneriler ile alanın uygulama sonrası durumları

\section{EĞITTIM FAKÜLTESI OTOPARKI}

\section{Öncesi 2016: Sorunlar / Tespitler}

Otopark düzensizdir; araçların park ve manevra alanı standartlara uygun değildir.

Mevcut ağaçların -Platanus orientalis (Doğu çınarı)- gelişimi için yeterli yeşil alan bırakılmamıştır.

Otoparkta gölge sağlayacak bitkisel düzenleme yetersizdir.
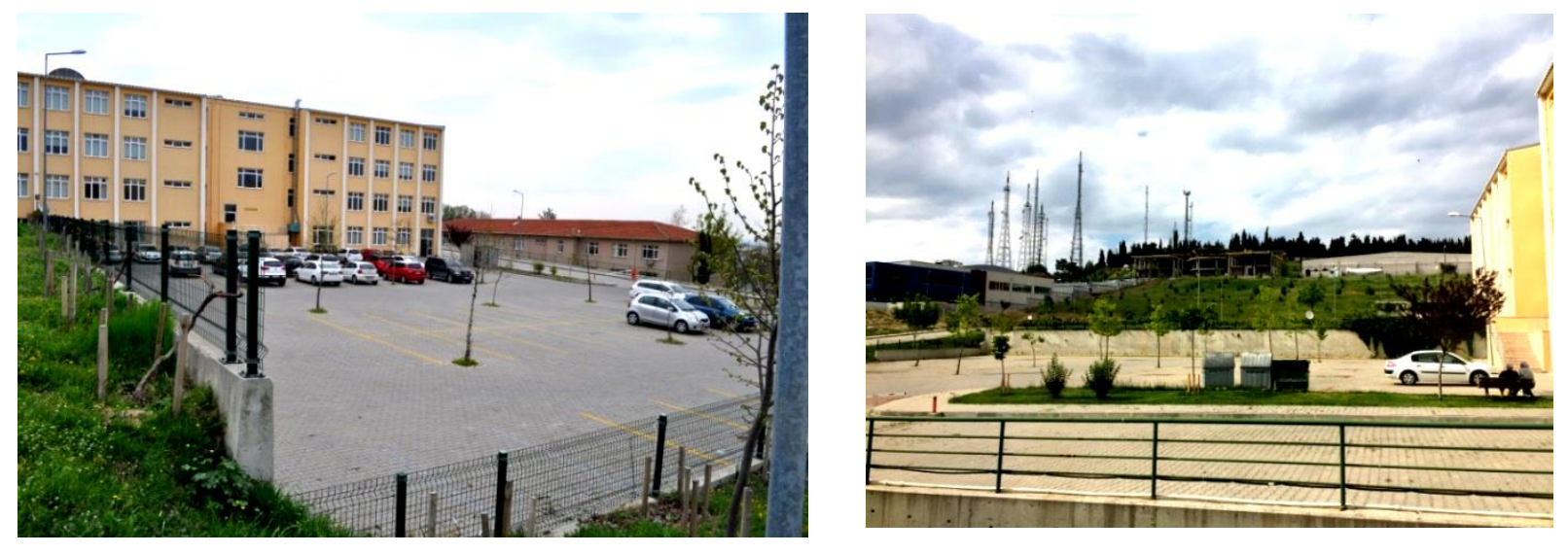

\section{Tasarım 2016: Öneriler}

Otopark giriş kontrol bariyeri ile kontrollü hale getirilmiş; araçların park düzeni çizilmiştir.

Mevcut bitkilerin gelişimi için yeterli yeşil alan bırakılmıştır.

Sınır duvarı herdem yeşil sarıcı bitkiler kullanılarak yeşil duvar haline getirilmiş; otoparkın sert görüntüsü yumuşatılmıştır.
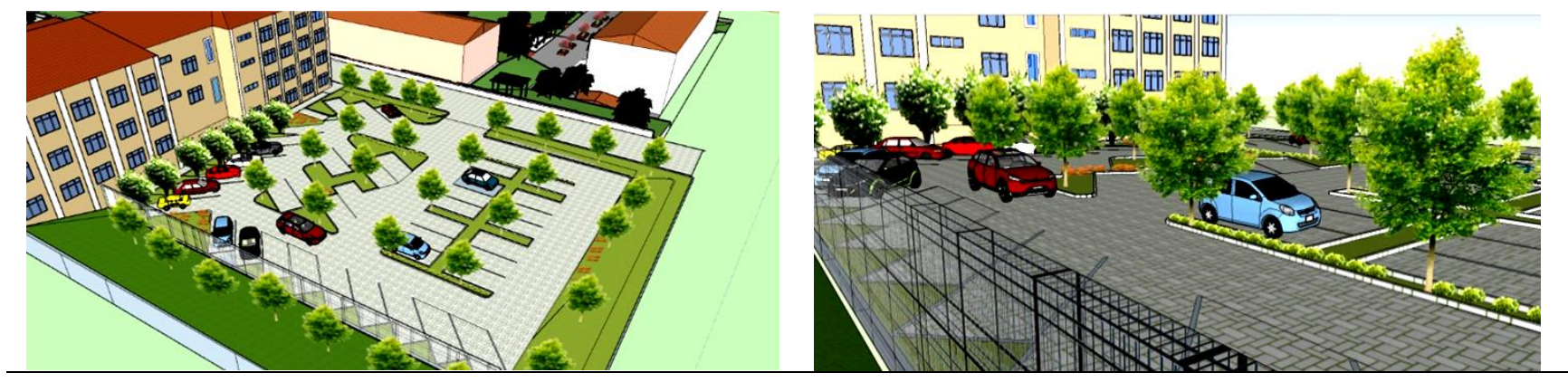

\section{Sonrası 2018: Uygulama}

Müdahalede bulunulmamıştır. 
Tablo 8. Kantin önü ve çevresine ait tespit ve öneriler ile alanın uygulama sonrası durumları

\section{KANTIN ÖNÜ VE ÇEVRESI}

\section{Öncesi 2016: Sorunlar / Tespitler}

Kantin önü tanımsız olup; sadece kilit parke taş kaplamalı zeminden oluşmaktadır.

Oturma birimleri gelişis güzel tüm alana yayılmıştır.

Binaya yakın kısımlara yerleştirilen oturma birimleri çalışanlar için gürültü problemi oluşturmaktadır.
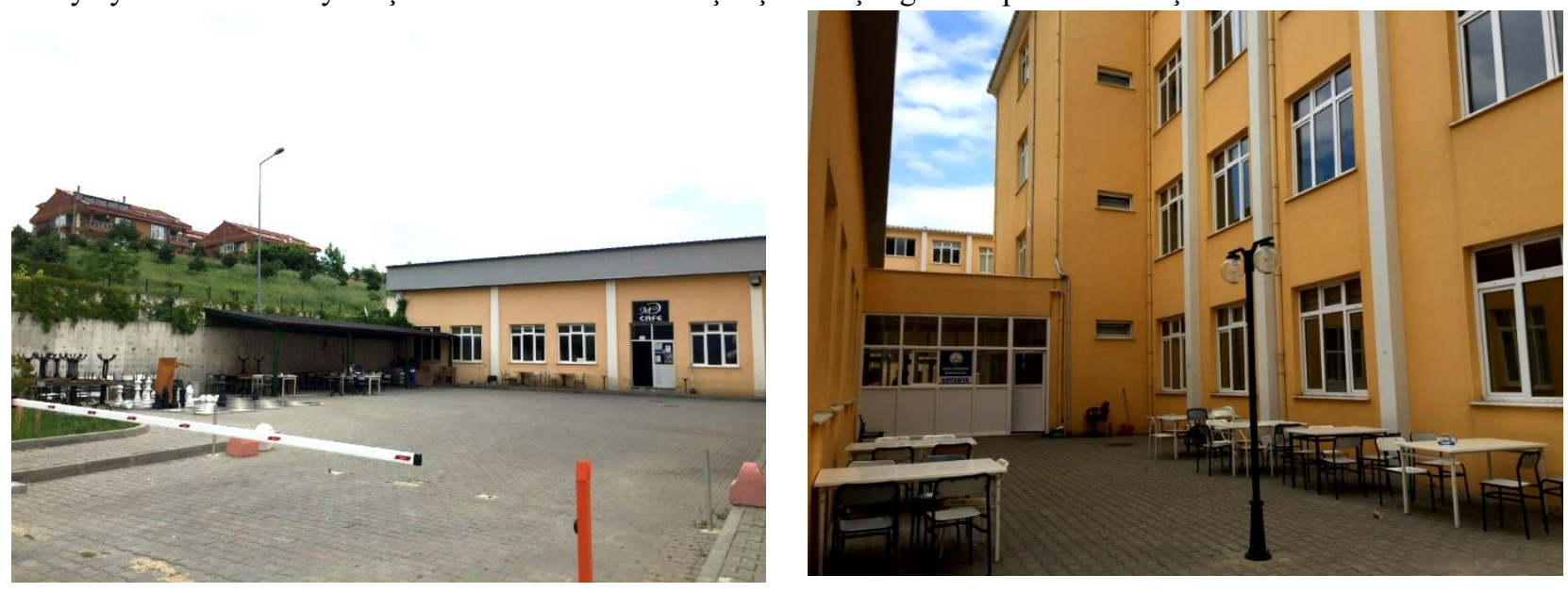

\section{Tasarım 2016: Öneriler}

Estetik görünüm sunabilmek ve gölge sağlayabilmek için mevcut alanda zemin kaplama malzemesinin bir kısmı kaldırılarak yeşil alan oluşturulmuşstur.

Yeşil alanın sınırı ahşap oturma elamanı olacak şekilde düzenlenmiştir.

Binaya yakın kısımlara ahşap saksılarda bitkiler yerleştirilerek alanın görüntüsü iyileştirilmiş ve gürültü denetimi adına katkıda bulunulmuştur.
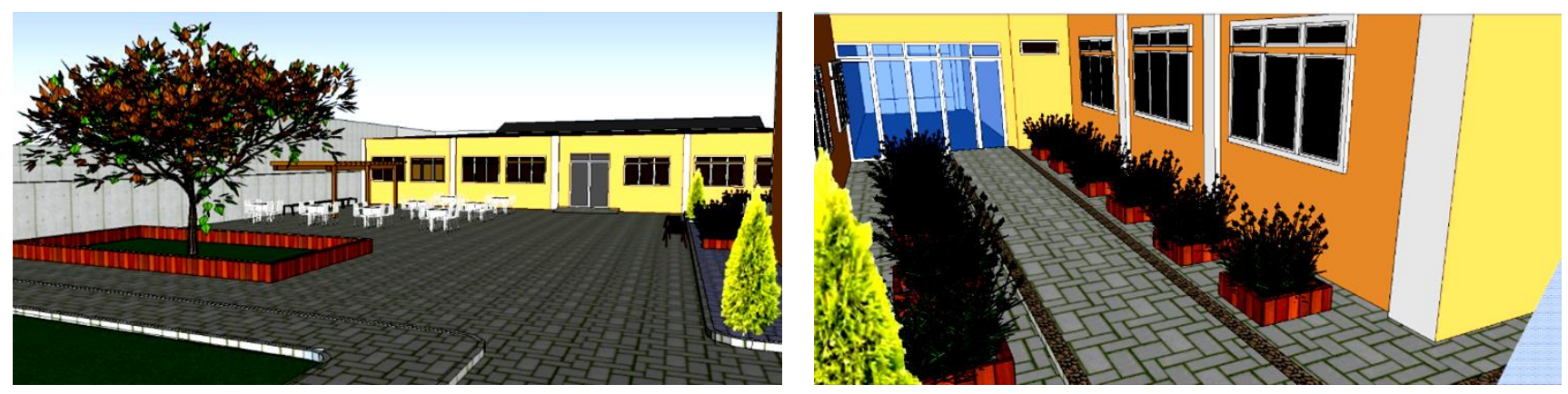

\section{Sonrası 2018: Uygulama}

Müdahalede bulunulmamıştır. 
Tablo 9. Konferans salonu çevresine ait tespit ve öneriler ile alanın uygulama sonrası durumları

\section{KONFERANS SALONU ÇEVRESI}

\section{Öncesi 2016: Sorunlar / Tespitler}

Alan sadece sert zemin ve istinat duvarlarından oluşmaktadır. Bakımsız ve atıl durumdadır. Verimli kullanılamamaktadır. Yeterli gölgelik alan yoktur.
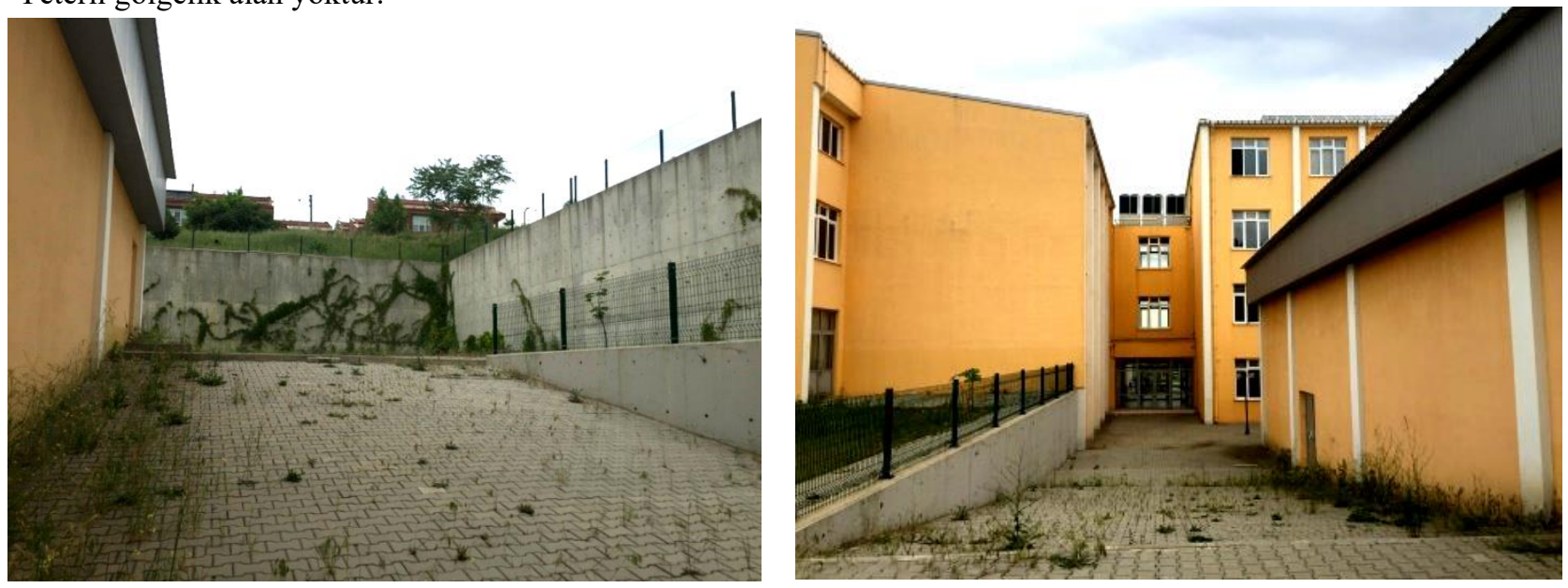

\section{Tasarım 2016: Öneriler}

Üst kottaki istinat duvarı da sarılıcı bitkiler ile yeşil duvar haline getirilmiştir.

Üst örtü elemanı ile gölgelik alan ve oturma birimi önerilmiştir.

Salon çıkışındaki duvar üzerinde bulunan metal bölücü elemanların kaldırılması önerilmiştir. Böylelikle yeşil alan ile bağlantı kurulması düşünülmüştür.

Bütünleşen bu alanların konferans salonuna hizmet eden bir açık mekân olarak kullanılması önerilmiştir.
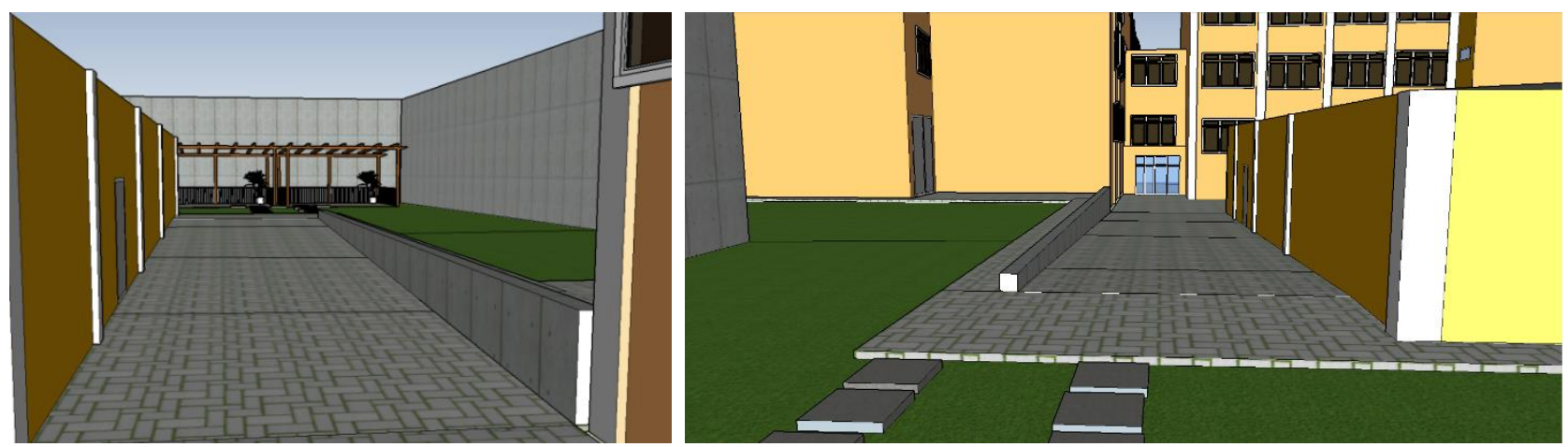

\section{Sonrası 2018: Uygulama}

Müdahalede bulunulmamıştır. 


\section{TARTIŞMA ve SONUÇ:}

Hazırlanan ön çalışma Temmuz 2016'da Eğitim Fakültesi Dekanlığı'na ekleriyle birlikte sunulmuştur (Şekil 3). Projenin uygulaması ve kontrolü Eğitim Fakültesi Dekanlığı'nca yürütülmüştür. Uygulama, proje önerisini hazırlayan Peyzaj Mimarlığı Bölümü öğretim üyeleri kontrolü olmaksızın gerçekleştirilmiş; bunun yanı sıra ekonomik ve zaman kısıtları olduğu düşünülen sebeplerle, projenin öneriye uygun halde gerçekleştirilmesi mümkün olmamıştır.
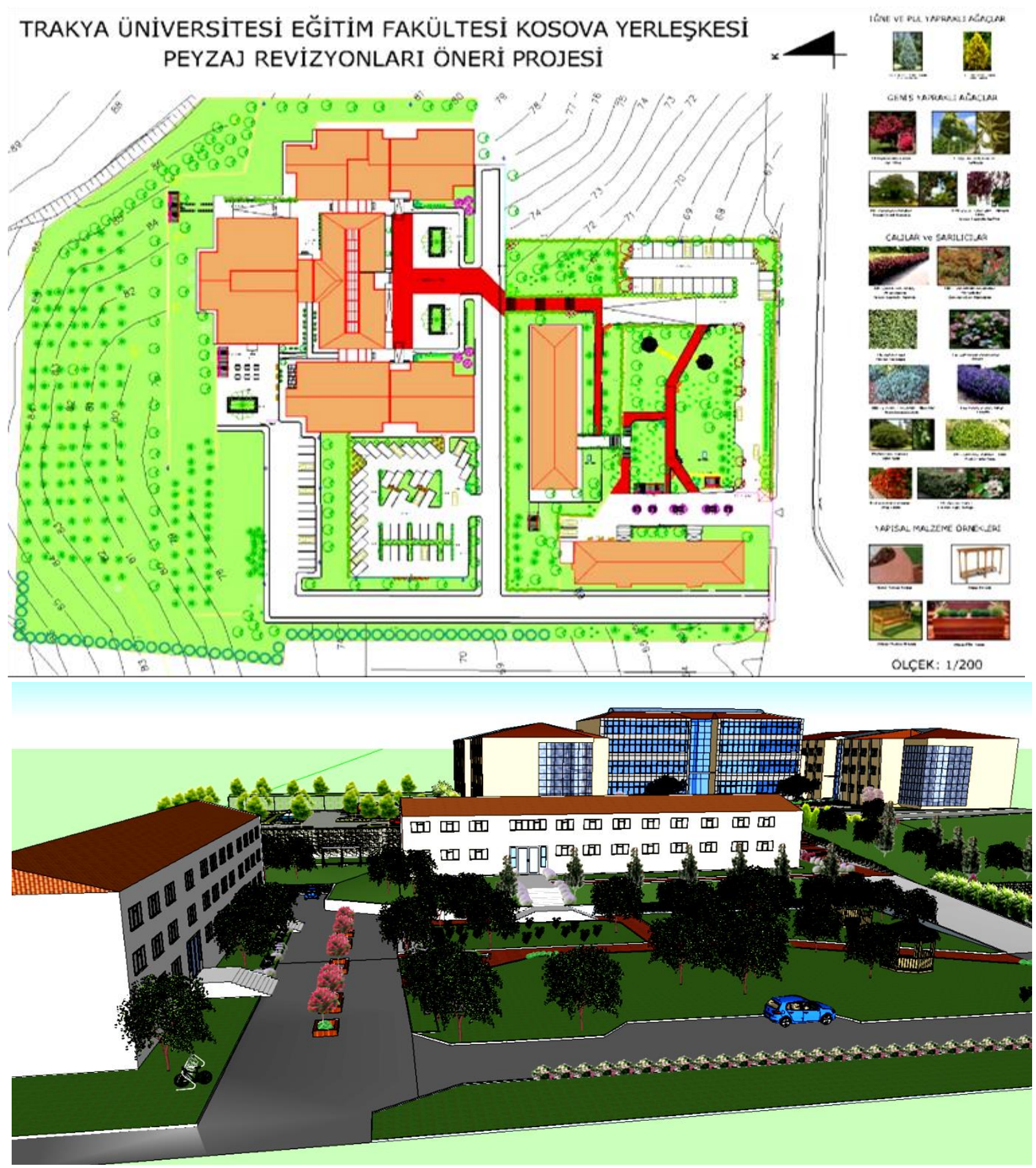

Şekil 3. T.Ü. Eğitim Fakültesi Kampüsü (Kosova Yerleşkesi) çevre düzenleme proje önerisi

A Landscape Designment Suggestion for Trakya University Faculty of Education Campus

Journal of Urban Academy | Volume: 13 Issue: 4 | ISSN: 2146-9229

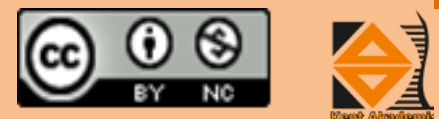


Gerçekleştirilen uygulamaların, hazırlanan öneri projeyle tam olarak örtüşmediği ve "Sonrası 2018: Uygulama" bölümünde çoğunlukla "müdahalede bulunulmamıştır” ifadesi göze çarpmaktadır (Tablo 2-9):

1. Yerleşke Girişi: Müdahalede bulunulmamıştır.

2. Güzel Sanatlar Bölümleri Binası önü: Önerilen bitkisel düzenlemeler gerçekleştirilmemiştir. Üst örtü elemanının öneriye uygun değiş̧irilmediği; malzeme olarak iyileştirildiği görülmektedir. Oturma birimlerinin Bina cephesindeki yenilik göze çarpmaktadır.

3. Dekanlık Binası önü: Döşemede, öneriye benzer şekilde renkli malzeme kullanıldığı, havuzun kaldırıldığı ve Dekanlık binasının önündeki yol ile birlikte yenilendiği görülmektedir.

4. Dekanlık Binası yanı: Müdahalede bulunulmamıştır.

5. Dekanlık otoparkı: İstinat duvarının kaldırıldığı, rampa eğiminin düzenlendiği, döşemelerin iyileştirildiği ve merdiven kaplama malzemesinin değiştirildiği görülmektedir. Yaya ve araç trafiğinin, farklı döşeme kaplamasıyla ayrımlandığı tespit edilmiştir. Otopark sınırını vurgulamak ve gölge sağlamak için önerilen bitkilendirmenin yapılmadığı görülmektedir.

6. Eğitim Fakültesi Binaları önü: Bu alanda önerilen ağaçlar ve düzenlemeler yerine üst örtülü oturma birimleri yerleştirildiği görülmektedir. Döşemelerin henüz iyileştirilmemesinin ekonomik sebeplerden kaynaklandığı düşünülmektedir.

7. Eğitim Fakültesi otoparkı: Müdahalede bulunulmamıştır.

8. Kantin önü ve çevresi: Müdahalede bulunulmamıştır.

9. Konferans Salonu çevresi: Müdahalede bulunulmamıştır.

Kısıtların ortadan kalktığı zaman dilimlerinde, uygulamaların devam edeceği umut edilmektedir.

Atabeyoğlu (2014) kampüs organizasyonlarında peyzaj planlama ve tasarım ilkelerinin göz önünde tutulması gereğini vurgulamaktadır. Yazar, dış mekânlarının tasarımında; çevresel karakterin korunması, mekânlar arasında iç mekân-dış mekân ilişkisinin, kentsel dokunun sürekliliğinin, ulaşılabilirliğin sağlanması, sembol oluşturma, resmiyet, algılanabilirlik, görsellik ve estetik gibi verilerin önemine değinmektedir. Kampüslerde yapılar dışında kalan açık alanların önemli bir bölümünün yeşil alanlara ayrıldığını belirten Karakaş, kampüslerdeki açık ve yeşil alanların işlevlerini şu şekilde sıralamaktadır (Karakaş, 1999):

- Kampüsün yapılarla olan dengesini sağlar

- Dolaşım sistemi için gerekli alanı sağlar

- Kampüste rekreasyon işlevine cevap verecek diş mekan düzenlemesine olanak verir

- Kampüsün sinırları içinde insanla çevresi arasında denge kurar

- Kampüsün fiziksel gelişimi için rezerv alanlar sağlar

- Kampüse estetik açıdan katkıda bulunur

Buna göre, öneri projede bitkisel tasarımın binalarla; hatta otopark ve sert zemin gibi tüm yapısal öğelerle denge oluşturması amacını barındırdığı ortaya konmuştur. Sirkülasyon ağının hem işlevsel hem estetik açıdan değerlendirilmesinin yanı sıra, yaya-taşıt kesişimlerini de göz önünde bulundurarak çözüm önerildiği görülmektedir. Kampüs alanında spor sahaları ve benzeri aktiviteler için gerekli alan bulunmamakla birlikte, tüm açık yeşil alanlar istekler ve ihtiyaçlar doğrultusunda düzenlenmiş; sosyalleşmeye olanak tanıyan dış mekan düzenlemeleriyle sunulmuştur. Belirlenen kampüs sınırları içinde mekan oluşturma, aidiyet ve güvenlik hissi yaratma hedefleri göz önünde bulundurulmuştur. Özellikle otopark alanlarında önerilen gölge ağaçları ile tüm bitkisel tasarım öğeleri, kampüsün ilerleyen yıllardaki rezervini oluşturmaktadır. Sınırlayıcı, gölge amaçlı, soliter kullanım, serbest kullanım, aks belirleyici olmak üzere farklı işlevlere sahip bitkisel öğelerin estetik açıdan katkıda bulunacağı kuşkusuzdur.

Ertekin ve Çorbacı (2010), kampüslerdeki açık ve yeşil alanların bir park şeklinde planlanmasının, gerek öğretim elemanları gerekse öğrencilerin kaliteli ve güvenli bir şekilde yaşamaları açısından önemli olduğunu belirterek; bu durumun eğitim ve öğretime olumlu olarak yansıdığını ifade etmektedirler. Üniversite kampüslerinde yer alan açık ve yeşil elemanlar yazarlar tarafından aşağıdaki gibi değerlendirilmiştir: 
- Kampüsün çevre sınırları,

- Kampüs girişleri,

- Aktif açık rekreasyon alanları,

- Pasif açik rekreasyon alanları,

- Taşıt sirkülasyon sistemi,

- Yaya sirkülasyon sistemi,

- Plastik objeler (çeşme, heykel, anıt),

- Kavşaklar,

- Dış mekân mobilyaları (pergola, bank, kameriye),

- Aydinlatma,

- Bitkilendirme,

- Özel uygulamalar

Çalışmada çevre sınırları ve girişler göz önünde bulundurulmuş olup, rekreasyon alanlarından pasif kullanıma imkan veren olanaklar değerlendirilmiştir. Araç ve yayalar için sirkülasyon üzerinde durulmuş, plastik objelerin kullanımı sınırlandırılmıştır. Dış mekan mobilyaları önerilmiş; bitkilendirme düzenlemeleri yapılmıştır. Kampüs alanında kavşak tasarlayacak alan bulunmamaktadır. Aydınlatma konusu değerlendirmeye alınmamıştır. Özel uygulamalar, binalar arasında kalan alanlarda noktasal çözümler olarak ifade edilmiştir.

Kampüsler, binalar ve binaları çevreleyen açık alanları ile bir bütünü ifade etmektedir. Öyle ki, içerdikleri işlevlerle ve buna bağl çalışma, eğitim, barınma, sosyalleşme, kültürel, dinlenme ve spor birimleriyle; yeşil alanları ve sirkülasyon bağlantılarıyla birlikte bir bütün olarak algılanmalı ve değerlendirilmelidir. Üniversitelerin eğitim ve öğretim faaliyetlerinin yanı sıra sosyal ve kültürel faaliyetleri ile birlikte işlev kazandığı yerleşim alanları olan kampüsler, kentsel kimliğe katkı sağlayan bölgeler olarak dikkat çekmektedir. Bu alanlarda akademik ve sosyal ortamlar arası ilişkilerin doğru kurgulanamaması veya nitelik açısından yetersizliği hem öğrenciler ve akademik-idari personel açıssından hem de kent bütününde imaj ve kimlik özelliği açısından sorun teşkil etmektedir. Dolayısıyla bu bütün içerisinde fiziksel çevrenin ve sosyal etkileşimin kullanıcılara en doğru şekilde sunulması önem arz etmektedir. Kampüs planlama ve tasarımda, doğru ve etkili mimari çözümlerle olduğu kadar peyzaj tasarımı ve ilkeleri ile de kullanıcıların beklentilerine cevap veren mekânlar oluşturulmak esas olmalıdır.

Bu çalışmada, Trakya Üniversitesi Eğitim Fakültesi Kampüsü (Kosova Yerleşkesi) için mevcut bina ve sert zemin yoğunluğu içerisinde, getirilen ekonomik kısttlara paralel olarak önerilen noktasal çözümler ve iyileştirmeler sunulmuştur. Kampüs planlama politikalarından dönüşümsel yaklaşım ele alınarak, erişilebilirlik ilkesiyle yaya odaklı strateji geliştirilmiş; yapısal ve bitkisel tasarım yapılmıştır. Yaya ve taşıt sirkülasyonu açısından iyileştirmek; sert zemin kullanımını azaltarak bitkisel öğelerle gerek işlevsel gerekse estetik ihtiyaçları gidermek, donatı gereksinimine yönelik çözüm üretmek amacıyla önerilen çevre düzenleme projesi açıklanmıştır. Projenin önerildiği kapsamda gerçekleştirilmesi için, gerek teknik ekibin önemi gerekse tasarım ve uygulama aşamalarının iş birliği içinde yürütülmesi gerekliliğinin önemi ortaya konmuştur.

\section{Teşekkür}

Trakya Üniversitesi Eğitim Fakültesi Kosova Yerleşkesi Çevre Düzenleme Projesi, Trakya Üniversitesi Mimarlık Fakültesi Peyzaj Mimarlı̆̆ Bölüm Başkanı Dr. Öğretim Üyesi H.Candan Zülfikar*, bölüm öğretim üyeleri Dr. Öğretim Üyesi Damla Atik ve Dr. Öğretim Üyesi Gökçen Bayrak tarafından tasarlanıp çizilmiş̧ir. Çalışma sürecinde bizlere yardımcı olan peyzaj mimarı Nilay Mısırlı*' ya teşekkür ederiz. Döner sermaye kapsamında maddi destekte bulunan Trakya Üniversitesi Rektörlüğü'ne ve Mimarlık Fakültesi Dekanlığı'na teşekkür ederiz. Ekonomik kısıtların ve çeşitli kalemlerdeki yoğun iş yükünün yarattı̆̆ı zorluklara rağmen, çevre düzenleme konusundaki ilgileri dolayısıyla Eğitim Fakültesi Dekanlığı'na teşekkür ederiz.

\footnotetext{
*: İstanbul Üniversitesi, Mimarlık Fakültesi, Şehir ve Bölge Planlama Bölümü Öğretim Üyesi

**: Trakya Üniversitesi, Mimarlık Fakültesi, Peyzaj Mimarlı̆̆g Bölümü Araştırma Görevlisi
} 


\section{Etik Standart ile Uyumluluk}

Çıkar Çatışması: Yazarlar herhangi bir çıkar çatışmasının olmadığını beyan eder.

Etik Kurul İzni: Bu çalışma için etik kurul iznine gerek yoktur.

Finansal Destek: Çalışma, Trakya Üniversitesi Rektörlüğü tarafından finanse edilmiştir.

\section{KAYNAKÇA:}

Akça, Ş. B., \& Gülgün Aslan, B. (2019). Kampüs Yaşamında Estetik ve Fonksiyonel Açıdan Süs Bitkilerinin Yeri ve Önemi; Çaycuma Kampüsü Örneği. Bartın Orman Fakültesi Dergisi, 21(2), 267-279.

Atabeyoğlu, Ö. (2014). Sosyal Bilimler Meslek Yüksekokulu Kampüsü Peyzaj Tasarım ve Uygulama Çalışması. Artium, 2(1), 85-101.

Birinci, N., Erdoğan, S., \& Birol, G. (2020). Bir Kamusal Temas Alanı Olarak Kampüs Açık Alanları: İzmir Demokrasi Üniversitesi Kampüs Tasarımı. Journal of Social and Humanities Sciences Research, 7(50), 232240.

Çorbacı, Ö. L., Turna, T., \& Ercan Oğuztürk, G. (2020). Kamusal Alanların Peyzaj Düzenlemesi Açısından Erişilebilirliğinin İncelenmesi; Dicle Üniversitesi Kampüsü Örneği. Journal of Forestry, 16(1), 105-127.

Erkman, U. (1990). Büyüme ve Gelişme Açısından Üniversite Kampüslerinde Planlama ve Tasarım Sorunları. İstanbul: İTÜ Mimarlık Baskı Atölyesi.

Ertekin, M., \& Çorbacı, Ö. L. (2010). Üniversite Kampüslerinde Peyzaj Tasarımı (Karabük Üniversitesi Peyzaj Projesi Örneği). Kastamonu Üniversitesi Orman Fakültesi Dergisi, 10(1), 55-67.

Karakaş, N. B. (1999). Üniversite Kampüslerinin Fiziksel Gelişim Planı Hazırlama Süresi ve Bartın Orman Fakültesi'nin Bu Bağlamda İrdelenmesi. Bartın: Yüksek Lisans Tezi, Zonguldak Karaelmas Üniversitesi Fen Bilimleri Enstitüsü.

Kurtoğlu, A. (2010). Kampüs Tasarımında Eylem Yönlendiricisi ile Sosyal Etkileşimin Değerlendirilmesi. İstanbul: Yüksek Lisans Tezi İstanbul Teknik Üniversitesi Fen Bilimleri Enstitüsü.

Matloob, F. A., Sulaiman, A. B., Ali, T. H., Shamsuddin, S., \& Mardyya, W. N. (2014). Sustaining Campuses Through Physical Character-The Role of Landscape. Procedia Social and Behavioral Science(140), $282-290$.

Öztürk, N. (2009). Üniversite Kampüs Yapıları ve Üniversite-Kent İlişkisi. İstanbul: Yüksek Lisans Tezi, İstanbul Teknik Üniversitesi Fen Bilimleri Enstitüsü.

Sağlık, E., Sağlık, A., \& Temiz, M. (2020). Landscape Design-Campus Walking Roads-Life Quality. GSI Journals Serie A: Advancements in Tourism, Recreation and Sports Sciences, 3(1), 31-43.

Turner, P. V. (1995). Campus An American Planning Tradition. Massachusets and London: The MIT Pres Cambridge.

Türeyen, M. (2002). Yükseköğretim Kurumları - Kampüsler. İstanbul: Tasarım Yayın Grubu.

URL 1. (2018). Ağustos 2018 tarihinde T.C. Trakya Üniversitesi Eğitim Fakültesi: http://egitimfak.trakya.edu.tr/ adresinden alınd 1

URL 2. (2020). Ekim 2020 tarihinde Google Earth. adresinden alındı

URL 3. (2018). Ağustos 2018 tarihinde Google Earth. adresinden alındı

Yerli, Ö., \& Özdede, S. (2017). Design Process of a Campus Plan: A Case Study of Düzce University Konuralp Campus. International Journal of Engineering Research and Application, 7(4), 50-59.

Yeşil, M. (2017). Ordu Üniversitesi Cumhuriyet Yerleşkesi Bitkisel Tasarımı ve Uygulaması. Iğdır Üniversitesi Fen Bilimleri Enstitüsü Dergisi, 7(2), 279-293.

Yılmaz, S. (2015). Bir Kampüs Açık Mekanının Peyzaj Tasarımı: Süleyman Demirel Üniversitesi Orman Fakültesi Binası. Kastamonu Üniversitesi Orman Fakültesi Dergisi(2), 297-307. 